\title{
Oprocentowanie i opłaty oraz zasady ich ustalania i zmian w bankowych wzorcach umów o indywidualne produkty emerytalne w kontekście stosowania w nich niedozwolonych klauzul umownych ${ }^{1}$
}

W procesie zawierania umów o indywidualne konta emerytalne (IKE) i indywidualne konta zabezpieczenia emerytalnego (IKZE) wykorzystywane sq wzorce umów (zwane także zamiennie wzorcami umownymi], które moga zawierać niedozwolone klauzule umowne. Artykuł zawiera wyniki badania empirycznego, obejmujacego większość wzorców umów dotyczących indywidualnych produktów emerytalnych oferowanych w Polsce przez banki. Potwierdzajq one występowanie w tych wzorcach klauzul abuzywnych naruszajacych interesy konsumentów, w szczególności w zakresie zmian oprocentowania, a także podstaw pobierania, ustalania wysokości i dokonywania zmian pobieranych przez banki opłat. Przedmiotem badania objęto zarówno sama konstrukcję analizowanych IKE i IKZE oferowanych przez wybrane banki, jak i stosowane przez nie w tym zakresie wzorce umowne. Celem było zbadanie treści bankowych wzorców umów o te produkty emerytalne pod kqtem stosowania w nich klauzul niedozwolonych dotyczqcych odpłatności za te produkty emerytalne, w szczególności w zakresie sposobu ustalania stopy oprocentowania, a także wysokości pobieranych opłat, w tym likwidacyjnych. Zastosowano następujace metody badawcze: krytycznq analizę piśmiennictwa, orzecznictwa SOKIK i wpisów do rejestru NKU prowadzonego przez Prezesa UOKiK oraz decyzji Prezesa UOKIK, a także ekonomicznq i prawnq analizę badanych IKE i IKZE jako produktów bankowych.

1. Badanie zostało w części zrealizowane i sfinansowane ze środków Narodowego Centrum Nauki w ramach projektu „Zrozumiałość, przejrzystość i efektywność indywidualnych produktów emerytalnych” (projekt nr 2016/21/D/HS5/03905). Chodzi o analizę mechanizmów ekonomicznych, sposobu ustalania oprocentowania oraz opłat pobieranych w indywidualnych produktach emerytalnych oferowanych przez banki. 
Słowa kluczowe: indywidualne konta emerytalne, indywidualne konta zabezpieczenia emerytalnego, klauzule abuzywne, wzorce umowne, oprocentowanie, opłaty likwidacyjne.

\section{Wstęp}

Publiczne, bazowe systemy emerytalne przeżywaja kryzys spowodowany przede wszystkim starzeniem się ludności i niemożnością wypłaty świadczeń dla coraz liczniejszej rzeszy emerytów przy coraz mniejszej liczbie osób aktywnych zawodowo i wpłacających składki emerytalne. Wprowadzone w ostatnich latach reformy tych systemów spowodowały obniżenie relatywnego poziomu świadczeń, wyrażonego jako stopa zastapienia wynagrodzenia świadczeniem. Pojawiło się w związku z tym pole do dodatkowego zabezpieczenia na emeryturę, które może funkcjonować w formie grupowej lub indywidualnej. Reforma bazowego systemu emerytalnego, którą wprowadzono w Polsce 1999 roku, nie spowodowała dynamicznego rozwoju dodatkowych form oszczędzania na starość. Do powołanych wówczas do życia pracowniczych programów emerytalnych (PPE) należało po 5 latach niespełna 130 tys. pracujących. W konsekwencji w kolejnych latach system był wzbogacany o różne nowe propozycje mające skłonić Polaków do dodatkowego oszczędzania na emeryturę 2 . Jedna z takich form były indywidualne konta emerytalne (IKE), wprowadzone w 2004 roku na podstawie ustawy o indywidualnych kontach emerytalnych ${ }^{3}$, do których od 2012 roku ${ }^{4}$ dołączyły indywidualne konta zabezpieczenia emerytalnego (IKZE). Różnica między nimi wynika jedynie z rodzaju stosowanej zachęty podatkowej i limitu wpłat. Oba rodzaje indywidualnych planów emerytalnych (IKE i IKZE) mogạ być oferowane w jednej z następujących form: funduszu inwestycyjnego, ubezpieczenia na życie z ubezpieczeniowym funduszem kapitałowym ${ }^{5}$, dobrowolnego funduszu emerytalnego, rachunku papierów wartościowych w domu maklerskim lub rachunku bankowego ${ }^{6}$, na podstawie umowy o prowadzenie IKE lub IKZE (art. 8 u.i.k.e.). Jest ona zawierana przez oszczędzającego (osobę fizyczna) w formie elektronicznej, pozwalającej na utrwalenie jej treści na trwałym nośniku, lub w formie pisemnej z uprawniona do tego instytucja finansową: $z$ funduszem inwestycyjnym, dobrowolnym funduszem emerytalnym, z podmiotem prowadzącym działalność maklerską, z zakładem ubezpieczeń na życie lub z bankiem.

Pomimo kilkunastu lat funkcjonowania indywidualnych planów emerytalnych w Polsce analizy z tego obszaru charakteryzują się ograniczonym zakresem. Nieliczne badania dotyczą

2. J. Rutecka i in., Dodatkowy system emerytalny w Polsce - diagnoza i rekomendacje zmian, Towarzystwo Ekonomistów Polskich, Warszawa, grudzień 2014; J. Berthon i in., Pension Savings. The Real Return. 2015 Edition, Better Finance, Brussels 2015, s. 226; A. Kolek, 0. Sobolewski, OFE, PPK, IKE[+] - Zmiany w systemie emerytalnym 2019-2021. Analiza prawno-ekonomiczna, „Monitor Prawniczy” 2020, nr 8, dodatek.

3. Ustawa z dnia 20 kwietnia 2004 r. o indywidualnych kontach emerytalnych (Dz. U. 2004, nr 116, poz. 1205). Aktualnie obowiązująca to: ustawa z dnia 20 kwietnia 2004 r. o indywidualnych kontach emerytalnych oraz indywidualnych kontach zabezpieczenia emerytalnego (tekst jedn. Dz. U. 2019, poz. 1808 z późn. zm.), dalej: u.i.k.e.

4. Od 1 stycznia 2012 r. wprowadzono IKZE, na podstawie art. 12 ustawy z dnia 25 marca 2011 r. o zmianie niektórych ustaw związanych z funkcjonowaniem systemu ubezpieczeń społecznych (Dz. U. 2011, nr 75, poz. 398). Zmieniono także tytuł ustawy o indywidualnych kontach emerytalnych na: „ustawę o indywidualnych kontach emerytalnych oraz indywidualnych kontach zabezpieczenia emerytalnego".

5. Wpłatą na IKE/IKZE jest jednak wyłącznie ta część składki, za którą nabywane są jednostki uczestnictwa UFK.

6. Art. 2 pkt 1 i pkt 1 u.i.k.e. 
Oprocentowanie i opłaty oraz zasady ich ustalania i zmian w bankowych wzorcach umów...

efektywności wybranych rodzajów IKE i IKZE? , efektów zachęt podatkowych ${ }^{8}$, ich zrozumiałości językowej i kosztowości ${ }^{9}$ czy charakterystyki prawnej ${ }^{10}$. Mimo że stosowane są kosztowne zachęty podatkowe - w postaci zwolnienia z podatku od dochodów kapitałowych w przypadku IKE oraz zwolnienia z opodatkowania składki i zastosowania obniżonej stopy opodatkowania świadczenia w przypadku IKZE - produkty te nie podlegają certyfikacji czy jakiejkolwiek wstępnej kontroli przed wprowadzeniem ich na rynek. Dotychczas nie badano zgodności treści wzorców umów (wzorów umów, regulaminów, tabel opłat i prowizji] dotyczących IKE i IKZE z obowiązującym prawem pod kątem stosowania w nich klauzul abuzywnych.

Nieprawidłowości dotyczące naruszania interesów oszczędzających (konsumentów ${ }^{11}$ ], w szczególności praktyki naruszające zbiorowe interesy konsumentów, były badane m.in. przez Małgorzatę Sieradzką ${ }^{12}$ i Jana Szuszkiewicza ${ }^{13}$. Ich analizy nie dotyczyły jednak stosowania we wzorcach umownych w zakresie IKE i IKZE klauzul abuzywnych, ale praktyk wprowadzajacych w błąd.

Z uwagi na to autorki niniejszego opracowania przedmiotem analizy uczyniły wzorce umowne dotyczące dobrowolnych, indywidualnych produktów emerytalnych, zarówno IKE, jak i IKZE, stosowanych przez banki w Polsce i oferowanych na podstawie umów o bankowe rachunki oszczędnościowe. Celem było zbadanie treści bankowych wzorców umownych dotyczących tych produktów emerytalnych pod kątem stosowania w nich klauzul niedozwolonych w zakresie odpłatności za nie (w szczególności: w odniesieniu do sposobu ustalania stopy oprocentowania, a także wysokości pobieranych opłat, w tym likwidacyjnych). Po kryzysie na rynku finansowym, w związku z niskimi

7. Ł. Dopierała, Efficiency of Pension Products Offered by Life Insurance Companies: the Case of Individual Pension Accounts, „Finanse i Prawo Finansowe” 2017, nr 2(14). doi: 10.18778/2391-6478.2.14.03; Ł. Dopierała, Indywidualne konta emerytalne prowadzone przez zakłady ubezpieczeń. Efektywność inwestycyjna i zasady funkcjonowania, Wydawnictwo Uniwersytetu Gdańskiego, Gdańsk 2018; E. Marcinkiewicz, Dobrowolne fundusze emerytalne w Polsce - analiza działalności i wyników inwestycyjnych, [w:] Współczesne problemy systemów emerytalnych. Wybrane zagadnienia, [red.] F. Chybalski, E. Marcinkiewicz, Wydawnictwo Politechniki Łódzkiej, Łódź 2015; J. Rutecka-Góra, Efficiency of a supplementary old-age pension system - the case of Polish voluntary pension funds, "Financial Internet Quarterly e-Finanse" 2019, nr 15(3), doi: 10.2478/fiqf-2019-0022; A. Maczyńska i in., Long-Term and Pension Savings. The Real Return. 2020 Edition, Better Finance, Brussels 2020.

8. J. Rutecka-Góra, Efekty zachęt podatkowych w dodatkowym systemie emerytalnym w Polsce, [w:] Ubezpieczenia. Wyzwania rynku, [red.] I. Kwiecień, P. Kowalczyk-Rólczyńska, CH Beck, Warszawa 2019, doi: 10.33119/978-83-8198-041-8_49-62.

9. J. Rutecka-Góra i in.,Zrozumiałość, przejrzystość i efektywność indywidualnych produktów emerytalnych w Polsce, Oficyna Wydawnicza SGH, Warszawa 2020, doi: 10.33119/978-83-8030-378-2.2020.202; S. Pieńkowska-Kamieniecka i in., Readability, efficiency and costliness of individual retirement products in Poland, "Equilibrium. Quarterly Journal of Economics and Economic Policy" 2021, Vol. 16 No. 1, 45-74, doi: 10.24136/eq.2021.002.

10. D. Maśniak, Indywidualne konta zabezpieczenia emerytalnego jako sposób wzmacniania bezpieczeństwa socjalnego, „Gdańskie Studia Prawnicze” 2013, nr 2, s. 79-88; T. Sowiński, Finanse ubezpieczeń emerytalnych, Wolters Kluwer, Warszawa 2009; A. Kolek, 0. Sobolewski, op. cit.

11. Chodzi o pojęcie konsumenta w rozumieniu definicji legalnej zawartej $w$ art. 221 ustawy z dnia 23 kwietnia 1964 r. - Kodeks cywilny (tekst jedn. Dz. U. 2019, poz. 1145 z późn. zm.), jako osoby fizycznej dokonujacej z przedsiębiorca ( w tym przypadku bankiem) czynności prawnej (zawarcia umowy rachunku bankowego IKE, IKZE], niezwiązanej bezpośrednio z jej działalnością gospodarczą lub zawodowa.

12. M. Sieradzka, Naruszenie obowiqzku informacyjnego we wzorcu umowy o prowadzenie indywidualnego konta emerytalnego (IKE) przez bank. Glosa do wyroku s. okręg. z dnia 3 grudnia 2013 r., XVII AmA 89/13, LEX/el. 2015.

13. J. Szuszkiewicz, Naruszenie bankowej umowy o prowadzenie rachunku IKE, „Monitor Prawa Bankowego” 2018, nr 3, s. 56-70. 
długoterminowymi stopami procentowymi, obserwuje się bowiem dużą skalę nadużyć interesów konsumentów poprzez stosowanie różnego typu niewłaściwych praktyk, w tym także w zakresie odpłatności za usługi finansowe ${ }^{14}$. Jest to także efekt występującej między profesjonalista, jakim jest bank, a konsumentem asymetrii informacji co do istoty i cech oferowanej usługi, ryzyk z nia związanych i odpłatności za nią ${ }^{15}$, ale także nierównowagi między stronami kontraktu (asymetrii kontraktowej], ${ }^{16}$ której przejawem jest także stosowanie wzorców umów. Szczególnie naganne i stosunkowo najczęstsze jest wprowadzanie w błąd w odniesieniu do odpłatności za usługę finansowa ${ }^{17}$, stwarzanie pozoru, że jest ona darmowa lub niezwykle korzystna, podczas gdy tak w rzeczywistości nie jest ${ }^{18}$, zazwyczaj z pominięciem informacji o zagrożeniach i ryzykach z nią związanych lub przekazywanych często w nieprzejrzysty, niekompletny i niejasny sposób ${ }^{19}$.

Skoncentrowano się na identyfikacji i charakterystyce postanowień umownych zawartych we wskazanych wzorcach umów, które mogłyby potencjalnie zostać uznane za niedozwolone klauzule umowne (NKU) lub zostały już za takie uznane bądź w drodze wyroku Sądu Ochrony Konkurencji i Konsumentów (SOKiK) i wpisane do prowadzonego przez Prezesa UOKIK rejestru ${ }^{20}$ (sądowy model abstrakcyjnej kontroli wzorców umownych), bądź w drodze decyzji Prezesa Urzędu Ochrony Konkurencji i Konsumentów (UOKiK) ${ }^{21}$.

Analizę przeprowadzono, wykorzystując następujące metody badawcze: krytyczną analizę piśmiennictwa, orzecznictwa SOKIK i wpisów do rejestru NKU prowadzonego przez Prezesa UOKiK] oraz decyzji Prezesa UOKIK, a także ekonomiczną i prawną analizę IKE i IKZE jako produktów bankowych.

14. Szerzej: E. Rutkowska-Tomaszewska, Misselling i inne nadużycia wobec konsumentów na rynku usług finansowych, [w: Nadużycia wobec konsumentów na rynku finansowym: wykrywanie, przeciwdziałanie, zapobieganie, [red.] A. Jurkowska-Zeidler, E. Rutkowska-Tomaszewska, A. Wiktorow, J. Monkiewicz, PWN, Warszawa 2020 i powoływana tam literatura oraz inne opracowania w tej monografii.

15. Por. E. Rutkowska-Tomaszewska, Usługifinansowe - dobrodziejstwo i (czy) zagrożenie dla konsumentów? Czy ochrona konsumenta usług finansowych jest obecnie efektywna i wystarczajaca?, [w:] Ochrona konsumenta na rynku usług, [red.] M. Jagielska, E. Sługocka-Krupa, K. Podgórski, CH Beck, Warszawa 2016, s. 40-41.

16. E. Rutkowska-Tomaszewska, Ochrona prawna klienta na rynku usług bankowych, Wolters Kluwer, Warszawa 2013, s. 327.

17. Szerzej patrz: E. Rutkowska-Tomaszewska, Manipulowanie informacja w zakresie odpłatności za usługi bankowe i prawne mechanizmy przeciwdziałania tym nadużyciom, [w:] Nowe koncepcje i regulacje nadzoru finansowego, [red.] W. Rogowski, Oficyna Allerhanda, Kraków-Warszawa 2014, s. 297 i nast.

18. E. Rutkowska-Tomaszewska, Usługi finansowe - dobrodziejstwo..., op.cit, s. 40-41.

19. Szerzej m.in. E. Rutkowska-Tomaszewska, Idea ochrony konsumenta przez informację na rynku usług finansowych. Dokqd zmierza? (powinna zmierzać?], [w:] Informacja na rynku usług finansowych, [red.] E. Rutkowska-Tomaszewska, Polskie Wydawnictwo Ekonomiczne, Warszawa 2019; E. Rutkowska-Tomaszewska, Aktualne trendy i wyzwania w zakresie ochrony konsumenta na rynku finansowym: dokqd zmierza (powinna zmierzać) ochrona konsumenta?: kilka wybranych uwag, [w:] Ekonomia jako dyscyplina naukowa i kierunek kształcenia: aktualne trendy i pożqqdane zmiany, [red.] E. Rutkowska-Tomaszewska, W. Kwaśnicki, Difin, Warszawa 2020, s. 262-263.

20. Rejestr klauzul abuzywnych prowadzony przez Prezesa UOKiK będzie obowiązywał do 17 kwietnia $2026 \mathrm{r}$. Wpisywane są do niego nadal klauzule, co do których toczy się postępowanie według dotychczasowych (poprzednio obowiązujących) przepisów, w których wniesiono pozwy do SOKiK przed 17 kwietnia 2016 r.

21. Od 17 kwietnia 2016 r. w Polsce obowiązuje model administracyjny abstrakcyjnej kontroli wzorców umownych wprowadzony ustawą z 5 sierpnia 2015 r. o zmianie ustawy o ochronie konkurencji i konsumentów oraz niektórych innych ustaw (Dz. U. 2015, poz. 1634). Oznacza to, że Prezes UOKIK wydaje decyzje o uznaniu postanowień wzorca umowy za niedozwolone i zakazuje ich stosowania. 
Oprocentowanie i opłaty oraz zasady ich ustalania i zmian w bankowych wzorcach umów...

Przedmiotem badania objęto zarówno samą konstrukcję analizowanych IKE i IKZE oferowanych przez wybrane banki, jak i stosowane przez nie w tym zakresie wzorce umów. Zgodnie z danymi Komisji Nadzoru Finansowego, na koniec 2019 roku22 indywidualne plany emerytalne oferowało 17 banków, w tym 9 banków spółdzielczych. Większość instytucji oferowała wyłącznie IKE (14 podmiotów), natomiast tylko dwa banki oferowały oba rodzaje produktów, a jeden posiadał wyłącznie ofertę IKZE (tabela 1.).

Tabela 1. Banki oferujące indywidualne produkty emerytalne na koniec 2019 roku

\begin{tabular}{|l|c|c|}
\hline \multicolumn{1}{|c|}{ Nazwa banku } & IKE & IKZE \\
\hline Alior Bank S.A. & + & \\
\hline Bank BGŻ BNP Paribas S.A. & + & \\
\hline Bank Millennium S.A. & + & \\
\hline Bank Polskiej Spółdzielczości S.A. & + & \\
\hline Bank Spółdzielczy w Będzinie & + & \\
\hline Bank Spółdzielczy w Brodnicy & + & \\
\hline Bank Spółdzielczy w Nidzicy & + & \\
\hline Getin Noble Bank S.A. & + & \\
\hline Idea Bank S.A. & + & \\
\hline Krakowski Bank Spółdzielczy & + & \\
\hline mBank S.A. & + & \\
\hline PKO Bank Polski S.A. & + & \\
\hline Podkarpacki Bank Spółdzielczy w Sanoku & + & \\
\hline SGB-BANK S.A. & + & \\
\hline Banki spółdzielcze zrzeszone w Banku Polskiej Spółdzielczości S.A. & + & \\
\hline Banki spółdzielcze zrzeszone w SGB Bank S.A. & + & + \\
\hline ING Bank Śląski S.A. & & + \\
\hline
\end{tabular}

Źródło: opracowanie własne na podstawie: KNF, Lista instytucji finansowych prowadzqcych IKE według stanu na dzień 31 grudnia 2019 roku, Warszawa 2020, https://www.knf.gov.pl/knf/pl/komponenty/img/IKE_lista_ podmioty_122019_69076.xls [dostęp: 23.12.2020]; KNF, Lista instytucji finansowych prowadzqcych IKZE według stanu na dzień 31 grudnia 2019 roku, Warszawa 2020, https://www.knf.gov.pl/knf/pl/komponenty/img/IKZE_lista_ podmioty_122019_69080.xls [dostęp: 23.12.2020].

Analizą objęto dokumenty pozyskane od instytucji bankowych w I połowie 2017 roku w ramach badania pt. „Zrozumiałość, przejrzystość i efektywność indywidualnych produktów emerytalnych”23, finansowanego ze środków Narodowego Centrum Nauki realizowanego w latach 2017-2020. Podmioty, których produkty oraz stosowane przez nich wzorce umowne zostały ocenione w trakcie badania, oznaczono w tabeli pogrubieniem (w sumie 9 instytucji). Z analizy wyłaczono banki, których wzorce umowne nie były dostępne na stronach internetowych i których nie udało się

22. KNF, Lista instytucji finansowych prowadzqcych IKE według stanu na dzień 31 grudnia 2019 roku, Warszawa 29 luty 2020, https://www.knf.gov.pl/knf/pl/komponenty/img/IKE_lista_podmioty_122019_69076.xls [dostęp: 23.12.2020]; KNF, Lista instytucji finansowych prowadzqcych IKZE według stanu na dzień 31 grudnia 2019 roku, Warszawa 2020, https://www.knf.gov.pl/knf/pl/komponenty/img/IKZE_lista_podmioty_122019_69080.xls [dostęp: 23.12.2020].

23. Projekt nr 2016/21/D/HS5/03905. 
pozyskać w drodze bezpośredniego kontaktu z instytucją finansową, a także produkty, które nie były oferowane nowym klientom z uwagi na ich wycofanie z rynku. Szczegółowy wykaz badanych wzorców umownych prezentuje tabela 2.

Tabela 2. Wykaz bankowych wzorców umownych objętych badaniem

\begin{tabular}{|c|c|}
\hline Nazwa banku & Nazwa wzorców umownych \\
\hline $\begin{array}{l}\text { Bank BGŻ BNP } \\
\text { Paribas S.A. }\end{array}$ & $\begin{array}{l}\text { Umowa ramowa rachunku oszczędnościowego indywidualnego konta emerytalnego IKE } \\
\text { obowiązująca do } 10 \text { listopada } 2016 \text { r. } \\
\text { Umowa rachunku oszczędnościowego indywidualnego konta emerytalnego IKE } \\
\text { Umowa ramowa rachunku oszczędnościowego indywidualnego konta emerytalnego IKE } \\
\text { Taryfa prowizji i opłat pobieranych przez Bank BGŻ BNP Paribas S.A. z tytułu } \\
\text { wykonywanych czynności bankowych oraz opłatach za wykonywanie innych czynności } \\
\text { Prowizje i opłaty pobierane za czynności bankowe od klientów detalicznych } \\
\text { na podstawie umowy }\end{array}$ \\
\hline $\begin{array}{l}\text { Bank Millennium } \\
\text { S.A. }\end{array}$ & $\begin{array}{l}\text { Ogólne warunki umowy indywidualnego konta emerytalnego } \\
\text { Cennik usług - stopy procentowe }\end{array}$ \\
\hline $\begin{array}{l}\text { Bank Polskiej } \\
\text { Spółdzielczości S.A. }\end{array}$ & $\begin{array}{l}\text { Regulamin rachunku oszczędnościowego POL-IKE Banku BPS S.A. } \\
\text { Tabela oprocentowania produktów bankowych Banku BPS S.A. } \\
\text { Taryfa opłat i prowizji bankowych Banku BPS S.A. dla klientów indywidualnych }\end{array}$ \\
\hline $\begin{array}{l}\text { Getin Noble Bank } \\
\text { S.A. }\end{array}$ & $\begin{array}{l}\text { Regulamin rachunków specjalnego przeznaczenia w Getin Noble Bank S.A. } \\
\text { (obowiązujacy od dnia } 1 \text { stycznia } 2017 \text { r.) } \\
\text { Tabela oprocentowania kont osobistych oraz kont oszczędnościowych dla klientów } \\
\text { indywidualnych w Getin Noble Bank S.A. } \\
\text { Tabela opłat i prowizji Getin Noble Bank S.A. dla klientów indywidualnych } \\
\text { (rachunek bankowych papierów wartościowych, indywidualne konto emerytalne) } \\
\text { (wg stanu na } 1 \text { stycznia } 2017 \text { r.) }\end{array}$ \\
\hline Idea Bank S.A. & $\begin{array}{l}\text { Regulamin otwierania i prowadzenia rachunku oszczędnościowego Indywidualnego } \\
\text { Konta Emerytalnego KONTO TAX FREE V w Idea Bank S.A. (obowiązujący } \\
\text { od } 11 \text { października } 2015 \text { r.) } \\
\text { Umowa rachunku oszczędnościowego Indywidualnego Konta Emerytalnego KONTO TAX } \\
\text { FREE V ” w Idea Bank S.A. } \\
\text { Regulamin otwierania i prowadzenia rachunku oszczędnościowego Indywiadualnego } \\
\text { Konta Emerytalnego w Idea Bank S.A. (obowiązuje od } 28 \text { kwietnia } 2016 \text { r.) } \\
\text { Regulamin promocji IKE idealne obowiązujący od } 28 \text { kwietnia } 2016 \text { r. } \\
\text { Tabela opłat i prowizji oraz tabela oprocentowania - rachunek oszczędnościowy } \\
\text { Indywidualnego Konta Emerytalnego „KONTO TAX FREE V”( obowiązująca w banku } \\
\text { od } 17 \text { listopada } 2014 \text { r.) } \\
\text { Tabela opłat i prowizji - rachunek oszczędnościowy Indywidualnego Konta Emerytalnego } \\
\text { (obowiązująca w banku od } 28 \text { kwietnia } 2016 \text { r.) } \\
\text { Tabela oprocentowania - rachunek oszczędnościowy Indywidualnego Konta } \\
\text { Emerytalnego (obowiązująca w banku od } 28 \text { kwietnia } 2016 \text { r.) }\end{array}$ \\
\hline ING Bank Ślaski S.A. & $\begin{array}{l}\text { Regulamin indywidualnego konta zabezpieczenia emerytalnego } \\
\text { Errata do regulaminu indywidualnego konta zabezpieczenia emerytalnego } \\
\text { Tabela stóp procentowych produktów depozytowych dla klientów indywidualnych } \\
\text { znajdujących się w bieżącej ofercie ING Bank Śląskiego S.A. (stan na } 12 \text { maja } 2017 \text { r.) } \\
\text { Regulamin świadczenia przez ING Bank Śląski S.A. usług w ramach prowadzenia } \\
\text { rachunków płatniczych dla osób fizycznych (obowiązujący od } 6 \text { sierpnia } 2018 \text { r.) } \\
\text { Tabela opłat i prowizji ING Banku Śląskiego S.A. dla osób fizycznych (tekst jednolity stan } \\
\text { na } 14 \text { marca 2017 r.) }\end{array}$ \\
\hline
\end{tabular}


Oprocentowanie i opłaty oraz zasady ich ustalania i zmian w bankowych wzorcach umów...

\begin{tabular}{|l|l|}
\hline $\begin{array}{l}\text { mBank S.A. } \\
\text { z oddziałem } \\
\text { zagranicznym }\end{array}$ & $\begin{array}{l}\text { Regulamin otwierania i prowadzenia rachunku oszczędnościowego indywidualnego } \\
\text { konta emerytalnego dla osób fizycznych w ramach bankowości detalicznej mBanku S.A. } \\
\text { (obowiązujacy od } 9 \text { czerwca } 2016 \text { r.) } \\
\text { Taryfa prowizji i opłat bankowych dla osób fizycznych w ramach bankowości detalicznej } \\
\text { mBanku S.A. (obowiązująca od } 30 \text { listopada } 2016 \text { r.) } \\
\text { Umowa o prowadzenie rachunku oszczędnościowego indywidualnego konta } \\
\text { emerytalnego }\end{array}$ \\
\hline $\begin{array}{l}\text { Krakowski Bank } \\
\text { Spółdzielczy }\end{array}$ & $\begin{array}{l}\text { Regulamin dla posiadaczy rachunków Indywidualnych Kont Emerytalnych } \\
\text { w Krakowskim Banku Spółdzielczym } \\
\text { Umowa o prowadzenie rachunku Indywidualnego Konta Emerytalnego } \\
\text { Taryfa prowizji i opłat Krakowskiego Banku Spółdzielczego dla klientów indywidualnych }\end{array}$ \\
\hline SGB BANK & $\begin{array}{l}\text { Umowa o prowadzenie Indywidualnego Konta Emerytalnego } \\
\text { Taryfa prowizji i opłat za czynności i usługi bankowe świadczone w walucie krajowej } \\
\text { - klienci SGB-BANKU S.A. (z wyłaczeniem zrzeszonych banków spółdzielczych) } \\
\text { obowiązujaca od } 10 \text { marca 2017 r. }\end{array}$ \\
\hline
\end{tabular}

Źródło: opracowanie własne.

\section{Rola wzorców umownych w kształtowaniu treści umów rachunku bankowego jako formy dodatkowego oszczędzania na emeryturę}

IKE i IKZE oferowane przez banki mają formę rachunku oszczędnościowego (art. 2 pkt 1 i 1 a u.i.k.e.), prowadzonego zgodnie z zasadami określonymi w Prawie bankowym ${ }^{24}$, z uwzględnieniem dodatkowych rozwiązań przewidzianych w przepisach u.i.k.e. (art. 32 u.i.k.e.). Są to szczególne rachunki oszczędnościowe ${ }^{25}$, które moga być prowadzone tylko przez bank krajowy ${ }^{26}$ (art. 2 pkt 9 u.i.k.e.). Do bankowej umowy IKE i IKZE w zakresie nieuregulowanym przez przepisy u.i.k.e. znajduja zastosowanie przepisy właściwe dla rachunku bankowego - czyli przepisy regulujace typowa, kodeksową umowę rachunku bankowego (art. 725-733 k.c.) oraz ustawy Prawo bankowe.

Konto emerytalne $w$ formie rachunku oszczędnościowego $w$ banku może być prowadzone wyłącznie dla jednej osoby fizycznej (art. 5 u.i.k.e.), a jeden oszczędzający może mieć tylko jedno IKE i IKZE, jeśli chce skorzystać z oferowanych zachęt podatkowych. Szczególne regulacje w odniesieniu do „emerytalnych” rachunków oszczędnościowych odnoszą się ponadto do rocznego limitu wpłat wynoszącego 300\% i 120\%27 przeciętnego prognozowanego miesięcznego wynagrodzenia w gospodarce odpowiednio w IKE i IKZE. Limity zostały wprowadzone ze względu na oferowane zwolnienia i ulgi podatkowe. W przypadku IKE występuje zwolnienie z podatku od dochodów kapitałowych, tzn. w ramach całego cyklu oszczędzania opodatkowana jest jedynie składka, a wypłata nie jest obciążona żadnym podatkiem ${ }^{28}$. Natomiast w przypadku IKZE oszczędzający moga odliczyć wpłacona składkę od podstawy opodatkowania, następnie zyski z lokowania środków są zwolnione z podatku od dochodów kapitałowych, a wypłata środków opodatkowana jest niższą, preferencyjną stawką wynoszącą $10 \%$.

24. Ustawa z dnia 29 sierpnia 1997 r. - Prawo bankowe (tekst jedn. Dz. U. 2020, poz. 1896), zwana dalej p.b.

25. Tak również: Z. Ofiarski, Prawo bankowe. Komentarz, Lex, Warszawa 2014; T. Sowiński, op. cit.

26. Zgodnie z art. 4 pkt ust. 1 pkt 1 p.b. jest nim bank mający siedzibę na terytorium Rzeczypospolitej Polskiej.

27. Od 1 stycznia 2021 obowiązuje także odrębny limit wpłat dla osób prowadzących pozarolniczą działalność gospodarczą równy $180 \%$ przeciętnego prognozowanego wynagrodzenia miesięcznego (art. 13a ust 1a u.i.k.e.).

28. Więcej: J. Rutecka i in., Dodatkowy ..., op.cit. 
Środki zgromadzone na IKE i IKZE w bankach są co do zasady oprocentowane, a umowa reguluje wysokość oprocentowania i przesłanki dopuszczalności jego zmiany przez bank, a także terminy wypłaty, postawienia do dyspozycji lub kapitalizacji należnych odsetek (art. 52 ust. 2 pkt 5 p.b.). Ustawa o IKE i IKZE nie wprowadza w tym zakresie żadnych szczególnych rozwiązań, wskazując jedynie, że w przypadku wypłaty transferowej, częściowego zwrotu albo zwrotu środków zgromadzonych na IKE lub IKZE bank przekazuje zgromadzone oszczędności wraz z należnym na dzień wypłaty transferowej, częściowego zwrotu albo zwrotu, oprocentowaniem naliczonym według zasad, jakie obowiązywałyby w przypadku kontynuacji umowy o prowadzenie IKE lub IKZE (art. 33 u.i.k.e.). Oznacza, to że bank nie może odmówić naliczenia odsetek za cały okres oszczędzania, gdy oszczędzający przenosi środki do innej instytucji finansowej, zleca wypłatę lub zwrot. Możliwość pobrania przez bank dodatkowej opłaty występuje jedynie w razie rozwiązania umowy o IKE bądź IKZE (przeniesienia środków) przed upływem 12 miesięcy od zawarcia umowy (art. 39 ust. 1 u.i.k.e.]. Wysokość opłaty likwidacyjnej musi być jednak określona w umowie o prowadzenie konta emerytalnego. Banki mogą także pobierać inne opłaty przewidziane w standardowym cenniku opłat dla posiadaczy rachunków. Wysokość prowizji i opłat za czynności związane z wykonywaniem umowy oraz przesłanki i tryb ich zmiany przez bank powinny być określone w umowie rachunku bankowego (art. 5 ust. 2 pkt 6 p.b.).

Umowa o prowadzenie IKE jest z założenia wieloletnia z uwagi na cel, jakim jest gromadzenie oszczędności emerytalnych. „Do zapewnienia adekwatnej ochrony interesów konsumentów wystarczające jest kodeksowe ograniczenie możliwości wypowiedzenia umowy rachunku bankowego z ważnych powodów, z uwagi na przewidziane w ustawie o IKE dodatkowe mechanizmy ochronne"29.

Umowy bankowe, w tym umowy rachunku bankowego, a co za tym idzie także umowa rachunku IKE i IKZE, są w większości umowami adhezyjnymi ${ }^{30}$, gdyż banki, posługujac się gotowymi wzorcami, ograniczają swobodę kontraktowania. Oznacza to, że do zawarcia takiej umowy dochodzi przez przystapienie kontrahenta banku do warunków zaproponowanych przez bank. Jej szczegółowe warunki, w tym prawa i obowiązki stron, określają wzorce umowne, które bank, podobnie jak inny przedsiębiorca, może stosować w obrocie masowym, na podstawie art. 384 i n. k.c.

Przepisy prawa w Polsce nie formułuja legalnej definicji wzorca umów (zwanego także powszechnie w doktrynie wzorcem umownym) ${ }^{31}$, a jedynie nim się posługują. Dopuszczając możliwość posługiwania się wzorcami przez przedsiębiorców, w tym także banki, art. 384 § 1 k.c. jako ich przykłady wymienia: ogólne warunki umów, wzory umów i regulaminy. Niezależnie od użytej nazwy, wzorce umowne są zbiorem klauzul umownych (postanowień umownych), opracowanym przez przedsiębiorcę, w tym bank, w oderwaniu od konkretnego stosunku umownego. Klauzule te w sposób jednolity (standardowy) określają treść przyszłych indywidualnych stosunków

29. Wyrok SA w Gdańsku - III Wydział Pracy i Ubezpieczeń Społecznych z 16 września 2009 r. sygn. III AUa 234/09, opubl. OSNAPiUS 2018/10/144, „Monitor Prawa Bankowego” 2019, nr 5, s. 31.

30. W. Pyzioł, Umowa rachunku bankowego, [w:] System Prawa Prywatnego. Tom 8, [red.] J. Panowicz-Lipska, CH Beck, Warszawa 2011; E. Niezbecka, Umowa rachunku bankowego, [w:] Kodeksowe umowy handlowe, [red.] A. Kidyba, LEX, Warszawa 2014; M. Sychowicz, Komentarz do art. 725, [w:] Komentarz do Kodeksu cywilnego. Księga trzecia. Zobowiqzania. Tom II, [red.] G. Bieniek, LexisNexis, Warszawa 2011.

31. Patrz m.in.: E. Rutkowska-Tomaszewska, Ochrona..., op.cit.; K. Skubisz-Kępka, [w:] Kodeks cywilny. Komentarz. Tom III. Zobowiqzania. Część ogólna (art. 353-534); [red.] M. Fras, M. Habdas, Wolters Kluwer, Warszawa 2018, art. 384; A. Olejniczak, [w:] Kodeks cywilny. Komentarz. Tom III. Zobowiqzania - część ogólna, [red.] A. Kidyba, Wolters Kluwer, Warszawa 2014, art. 384. 
Oprocentowanie i opłaty oraz zasady ich ustalania i zmian w bankowych wzorcach umów...

zobowiązaniowych nawiązywanych na podstawie umów ${ }^{32}$. W praktyce moga występować pod różnymi nazwami: instrukcje, taryfy prowizji i opłat, tabele opłat, cenniki, umowy typowe, umowy standardowe (wzory umów), regulaminy, ogólne warunki umów, umowy ramowe itp. Bogactwo stosowanych w obrocie przez przedsiębiorców nazw wzorców umownych, odzwierciedla także ich zróżnicowanie w badanych bankowych wzorcach umownych dotyczących IKE i IKZE (tabela 2.).

Bank, stosujac wzorzec umowny, także w zakresie IKE i IKZE, musi spełnić zarówno przesłanki formalne (odnoszące się do trybu zakomunikowania wzorca kontrahentowi), jak i merytoryczne (odnoszące się do treści zawartych we wzorcu postanowień - brak niedozwolonych postanowień umownych oraz transparencja), aby wzorzec skutecznie wiązał konsumenta ${ }^{33}$. Mimo pozytywnego wpływu wykorzystania w praktyce bankowej wzorców umownych na szybkość i wygodę zawierania umów, zarówno po stronie banku, jak i konsumenta, nie można pominąć zagrożeń dla interesów konsumentów. Za pośrednictwem wzorców mogą być im bowiem narzucane krzywdzące dla nich niedozwolone klauzule umowne (klauzule abuzywne).

Stąd też ustawodawca unijny ${ }^{34}$ (a w następstwie tego - polski) w celu ochrony konsumenta wprowadził ograniczenia w zakresie kształtowania treści wzorców umownych ${ }^{35}$, w postaci zakazu stosowania w nich niedozwolonych klauzul umownych (zakazana praktyka konsumencka art. 23 a u.o.k.ik. ${ }^{36}$ ) i ustanowienia cywilnoprawnej sankcji - w postaci ich bezskuteczności i braku związania nimi konsumenta (art. $385^{1} \S 2$ k.c.).

Niedozwolone klauzule umowne (art. $385^{1}-385^{3}$ k.c.) sa postanowieniami jednostronnie narzuconymi (takie, na które konsument nie miał wpływu, które nie zostały z nim uzgodnione indywidualnie $]^{37}$, kształtującymi prawa i obowiązki konsumenta w sposób sprzeczny z dobrymi obyczajami i rażąco ${ }^{38}$ naruszającymi jego interesy (jakiekolwiek, nie tylko ekonomiczne). Nie określają one głównego świadczenia stron, w tym ceny lub wynagrodzenia, chyba że nie zostały sformułowane w sposób jednoznaczny (transparentny). Klauzule abuzywne naruszają równowagę praw i obowiązków stron na niekorzyść konsumenta w stosunku obligacyjnym i godzą w jego równowagę kontraktową, przerzucając ryzyko gospodarcze prowadzonej działalności na niego ${ }^{39}$.

Poza generalną definicją klauzuli abuzywnej (art. $385^{1}$ k.c.), ustawodawca wprowadził również listę przykładowych klauzul, które mogą być uznane za abuzywne (art. $385^{3}$ k.c.). Są to postanowienia m.in.: przyznające przedsiębiorcy uprawnienia do jednostronnego kształtowania

32. E. Rutkowska-Tomaszewska, Ochrona..., op.cit.

33. Ibidem.

34. Dyrektywa Rady 93/13/EWG z dnia 5 kwietnia 1993 r. w sprawie nieuczciwych warunków w umowach konsumenckich (Dz.U.UE.L.1993.95.29 z dnia 1993.04.21).

35. E. Rutkowska-Tomaszewska, Misseling...

36. Ustawa z dnia 16 lutego 2007 r. o ochronie konkurencji i konsumentów (tekst jedn. Dz. U. 2021, poz. 275), dalej: u.o.k.ik.

37. W szczególności odnosi się to do postanowień umowy przejętych z wzorca umowy zaproponowanego konsumentowi przez kontrahenta (art. $385^{1} \S 3$ k.c.).

38. Przesłanki uznania klauzul umownych za abuzywne były interpretowane w wielu orzeczeniach sądów (np. wyroki SOKiK: z 17 września 2012 r., sygn. XVII AmC 5381/11; z 19 czerwca 2002 r., sygn. XVII AmC 34/01; z 21 stycznia 2013 r., sygn. XVII AmC 1584/12, a także wyrok SN z 13 lipca 2005 r., sygn. I CK 832/04, Biul. SN 2006, nr 2, s. 86).

39. I. Wesołowska, Niedozwolone postanowienia umowne, [w:] Standardy wspólnotowe w polskim prawie ochrony konsumenta, [red.] C. Banasiński, Wydawnictwo Prawo i Praktyka Gospodarcza, Warszawa 2004, s. 182; E. Łętowska, Ustawa o ochronie niektórych praw konsumentów. Komentarz, CH Beck, Warszawa 2002. 
praw i obowiązków stron; ograniczające prawa konsumenta lub zwiększające jego obowiązki, bez zachowania symetrii w stosunku do praw (obowiązków) przedsiębiorcy; ograniczające bạdź wyłączające odpowiedzialność przedsiębiorcy; wyłączające lub ograniczające znaczenie rzeczywistej woli konsumenta. Poza postanowieniami określonymi w art. $385^{3}$ k.c. także inne klauzule umów lub wzorców umownych mogą być kwalifikowane jako niedozwolone.

Niedozwolone postanowienia umowne nie wiążą konsumenta (są bezskuteczne), jednak w pozostałym zakresie strony są związane umowa ( $\operatorname{art} 385^{1} \S 2$ k.c.), niemniej sporo w praktyce jest problemów z rzeczywistym zastosowaniem tej z założenia dotkliwej dla przedsiębiorców sankcji o charakterze cywilnoprawnym ${ }^{40}$.

Konsument może dochodzić swoich roszczeń związanych z zastosowaniem klauzuli abuzywnej i żądać uznania jej w konkretnym przypadku za bezskuteczna z dalszymi konsekwencjami przed sądem powszechnym (sądem cywilnym) w ramach tzw. kontroli incydentalnej (indywidualnej). Poza tym Prezes UOKIK, w ramach kontroli abstrakcyjnej wzorców umownych, wydaje decyzję o uznaniu postanowienia wzorca umowy za niedozwolone ${ }^{41}$ i zakazuje jego wykorzystywania, a prawomocna decyzja w tym zakresie ma skutek wobec przedsiębiorcy, w stosunku do którego została ona wydana, a także wobec konsumentów, którzy zawarli z tym przedsiębiorcą umowę na podstawie wzorca umownego, w którym znalazło się abuzywne postanowienie umowne (rozszerzona skuteczność decyzji o uznaniu postanowienia wzorca za niedozwolone - art. 23d u.o.k.ik.). Przytacza w niej treść postanowienia wzorca umowy uznanego za niedozwolone, ale także może określić środki usunięcia trwających skutków naruszenia tego zakazu (art. 23b u.o.k.ik.).

\section{Ogólna charakterystyka klauzul abuzywnych w bankowych wzorcach umownych dotyczących IKZE i IKE na podstawie analizy treści wybranych wzorców}

Bankowe wzorce umowne i klauzule abuzywne stanowią istotny obszar orzecznictwa sadów powszechnych $^{42}$. Jego analiza pozwala na ustalenie pewnych reguł związanych z ich wykorzystaniem w praktyce bankowej ${ }^{43}$.

Wśród nich można wymienić m.in.:

40. E. Rutkowska-Tomaszewska, Prawo ochrony konsumenta usług finansowych w świetle założenia racjonalnego ustawodawcy: kilka wybranych uwag, „Acta Universitatis Wratislaviensis. Przegląd Prawa i Administracji” 2020, t. 120, doi: 10.19195/0137-1134.120.85.

41. Decyzje wydane przez Prezesa UOKiK są dostępne na stronie https://decyzje.uokik.gov.pl/bp/dec_prez.nsf [dostęp: 10.12.2020].

42. Patrz m.in. na gruncie umów rachunku bankowego: uchwała SN z 22 maja 1991 r., sygn. III CZP 15/91, OSNCP 1992/1, poz. 1; wyrok SN z 11 kwietnia 2013 r., sygn. II CSK 456/12, OSNC 2013/12, poz. 144; wyrok SN z 8 grudnia 2010 r., sygn. V CSK 163/10, OSNC-ZD 2011/B, poz. 48; wyrok SN z 17 grudnia 2008 r., sygn. I CSK 205/08, LEX nr 471143; wyrok SN z 27 października 2016 r., sygn. V CSK 48/16, LEX nr 2165600; wyrok Sądu Apelacyjnego w Szczecinie - I Wydział Cywilny z 13 czerwca 2016 r., sygn. I ACa 23/15, Legalis Numer 1509204; wyrok Sądu Apelacyjnego w Warszawie - V Wydział Cywilny z 7 sierpnia 2013 r., sygn. VI ACa 46/13 Numer 1049165; wyrok SN z 5 kwietnia 2002 r., sygn. II CKN 933/99, LEX nr 54492.

43. Zob. szerzej: E. Niezbecka, [w:] Kodeksowe umowy handlowe, [red.] A. Kidyba, Warszawa LEX 2014. 
- dla związania drugiej strony (w tym konsumenta) treścią wzorca umownego (także zmienianego pod warunkiem prawidłowo sformułowanej klauzuli modyfikacyjnej], konieczna jest także jego skuteczna inkorporacja do stosunku prawnego nawiązanego przez strony przy jego użyciu, gdyż nie mają one mocy obowiązującej, jaka cechuje przepisy prawne - nie mają charakteru normatywnego ${ }^{44}$;

- brak dopuszczalności zastrzegania w regulaminie (i innym wzorcu umowy) uprawnienia do jednostronnej zmiany warunków umowy bez możliwości jej wypowiedzenia przez konsumenta ${ }^{45}$;

- brak dopuszczalności dokonywania jednostronnej zmiany treści wzorca umownego, zwłaszcza w odniesieniu do wysokości stopy oprocentowania oraz opłat i prowizji, jeżeli w umowie strony nie zastrzegły jednocześnie możliwości jej zmiany ${ }^{46}$ i nie zostały określone konkretne okoliczności, od jakich zmiana ta jest uzależniona (prawidłowo sformułowana tzw. klauzula modyfikacyjna ${ }^{47}$;

- obowiązek informowania konsumenta o wszelkich zmianach w trakcie trwania umowy (np. zmianach taryfy opłat i prowizji) w taki sposób, aby mógł on zapoznać się z treścią tego zawiadomienia, a wszelkie dodatkowe opłaty za określone usługi muszą być uzasadnione ponoszonymi przez bank wydatkami ${ }^{48}$;

- zmiana wzorca umowy bankowej (w tym rachunku bankowego) w odniesieniu do stawek prowizji i opłat wymaga doręczenia konsumentowi zmienionych postanowień wzorca, a bank nie może ograniczyć się jedynie do wywieszenia wzorca umowy w oddziale banku lub poinformowania o nim konsumenta ${ }^{49}$.

Aby stwierdzić, czy w badanych wzorcach umów dotyczących indywidualnych produktów emerytalnych oferowanych przez banki występowały niedozwolone klauzule umowne, w szczególności odnoszące się do odpłatności (oprocentowania i opłat), dokonano analizy dotychczasowych wpisów do rejestru NKU, a także wydanych w latach 2016-2020 decyzji Prezesa UOKIK według stanu na koniec grudnia 2020 roku $^{50}$. Do analizy wybrano jedynie te NKU, które wprost dotyczyły rachunków bankowych lub odpłatności za usługi bankowe, z uwagi na zakres przedmiotowy prowadzonych badań nad niedozwolonymi klauzulami umownymi w bankowych wzorcach umownych

44. Tak wyrok SN z 7 lipca 2005 r., sygn. V CKN 855/04, ,Przegląd Ustawodawstwa Gospodarczego" 2005, nr 10, s. 33.

45. Uchwała składu ? sędziów SN z 22 maja 1991 r., sygn. III CZP 15/91, OSNC 1992, nr 1, poz. 1; wyrok SN z 5 kwietnia 2002 r., sygn. II CKN 933/99, LEX nr 54492.

46. Tak SN w uchwale z 3 lipca 1991 r., sygn. III CZP 59/91, OSNC 1992, nr 3, poz. 41 i w uchwale SN z 26 listopada 1991 r., sygn. III CZP 121/91, OSNCP 1992, nr 6, poz. 99.

47. Uchwała składu 7 sędziów SN z 6 marca 1992 r., sygn. III CZP 141/91, OSNC 1992, nr 6, poz. 90; wyrok SN z 5 kwietnia 2002 r., sygn. II CKN 933/99, LEX nr 54492. wyrok Sądu Apelacyjnego w Warszawie z 6 sierpnia 2010 r., sygn. VI A Ca 88/10; wyrok Sadu Apelacyjnego w Warszawie z 27 października 2010 r., sygn. VI a Ca 775/10; wyrok Sądu Apelacyjnego w Warszawie z 21 października 2011 r., sygn. VI ACa 420/2011; wyrok SN z 4 listopada 2011 r., sygn. I CSK 46/11; postanowienie SN z 21 grudnia 2011 r., sygn. ICSK 310/11.

48. Uchwała SN z 18 sierpnia 1992 r., sygn. III CZP 99/92, OSNC 1993, nr 1-2, poz. 20; wyrok SN z 17 lutego 2005 r., sygn. I CK 509/04, „Monitor Prawniczy” 2005, nr 6, s. 276.

49. Wyrok SN z 17 lutego 2005 r., sygn. I CK 509/04, „Prawo Bankowe” 2006, nr 12, s. 41.

50. Chodzi tu o: decyzję Prezesa UOKIK nr DOZIK-9/2020 z 3 sierpnia 2020 dot. Deutsche Bank Polska S.A. z siedzibą w Warszawie; decyzję Prezesa UOKIK, Nr RLU-1/2020 z 10 lipca 2020 dot. Idea Bank S.A. z siedzibą w Warszawie; decyzję Prezesa UOKiK nr D0ZIK-9/2018 z 31 grudnia 2018 dot. Deutsche Bank Polska S.A. z siedzibą w Warszawie; decyzję Prezesa UOKIK, Nr: RLU-2/2020, z 23 października 2020 dot. Getin Noble Bank S.A. z siedzibą w Warszawie. Analizowane decyzje Prezesa UOKIK są dostępne pod adresem: https://decyzje.uokik.gov.pl/bp/dec_prez.nsf. 
dotyczących IKE i IKZE. Pozwoliło to na przeanalizowanie badanych wzorców umownych pod kątem stosowania w nich przez banki niedozwolonych klauzul umownych w zakresie odpłatności za usługi bankowe w odniesieniu do opłat i prowizji i oprocentowania (klauzule dotyczące odpłatności za usługi bankowe], z uwagi na ich podobieństwo lub tożsamość do klauzul wpisanych do rejestru NKU oraz decyzji Prezesa UOKiK.

Przeprowadzona analiza potwierdziła, że w odniesieniu do umów rachunku bankowego klauzule abuzywne najczęściej dotyczą szeroko rozumianej odpłatności za usługi czy też uprawnienia do jednostronnego kształtowania treści umów i ich zmian w przyszłości (tzw. klauzule modyfikacyjne). Odnoszą się one do zmiany wysokości oprocentowania, opłat i prowizji (tabel opłat i prowizji) w trakcie trwania umowy oraz do wyłączenia odpowiedzialności banku.

Duża liczba stwierdzonych już NKU dotyczy uprawnienia banku do dokonywania w przyszłości zmian wzorca w trakcie trwania umowy (właściwie stosunku prawnego zawartego na podstawie umowy), czyli prawidłowo skonstruowanej klauzuli modyfikacyjnej ${ }^{51}$. Zaznaczyć trzeba, że nie może ona uprawniać do zmian naruszających istotę umowy i mieć charakter blankietowy (ogólny). Musi konkretnie wskazywać sytuacje, których zaistnienie uprawnia do zmiany stosunku prawnego w przyszłości. W przypadku gdy w umowie nie przewidziano uprawnienia do zmiany treści stosunku prawnego dla jednej ze stron, to art. $384^{1}$ k.c. w ogóle nie znajdzie zastosowania. Dopiero gdy tego rodzaju upoważnienie zostało sformułowane w sposób prawidłowy (prawidłowo skonstruowana klauzula modyfikacyjna) i tym samym ważny (m.in. w obrocie konsumenckim przy zastosowaniu klauzul niemających charakteru abuzywnego), art. $384^{1}$ k.c. znajduje zastosowanie ${ }^{52}$.

Niezamieszczenie w regulaminie (umowie) klauzuli zmiennego oprocentowania lub postanowienia dotyczącego możliwości dokonania zmiany opłat i prowizji skutkuje brakiem możliwości dokonania ich zmiany. Postanowienie o zmiennej stopie oprocentowania oraz zmianie opłat i prowizji, by mogło być uznane za poprawnie sformułowane i wiążące konsumenta, musi spełniać następujące przesłanki:

- zawierać szczegółowe wskazanie okoliczności mających wpływ na zmianę oraz, w miarę możliwości, określenie zależności między nastapieniem danej okoliczności a rozmiarem zmiany;

- być zgodne z wymogiem transparencji (art. 385 § 2 k.c.);

- nie mieć charakteru abuzywnego (na gruncie art. $385^{3}$ k.c. w zw. z art. $385^{1} \S 1$ k.c.);

- konsument w treści klauzuli musi być poinformowany o prawie do wypowiedzenia umowy w odpowiednim terminie, w przypadku gdy nie zgadza się na zaproponowane zmiany ${ }^{53}$.

Wśród klauzul abuzywnych - wpisanych do rejestru oraz tych w badanych wzorcach - znajduja się takie, które nakładają na konsumenta dodatkowe uciążliwe obowiązki lub też przyznają bankowi różnego rodzaju przywileje, w tym ustanawiające swego rodzaju fikcję doręczenia wzorca albo związane z zaniedbaniem obowiązku podania transparentnej informacji. Chodzi np. o postanowienia,

51. Na temat klauzul modyfikacyjnych patrz także: wyrok Sądu Apelacyjnego w Warszawie z 6 sierpnia 2010 r., sygn. VI A Ca 88/10; wyrok Sądu Apelacyjnego w Warszawie z 27 października 2010, sygn. VI a Ca 775/10; wyrok Sądu Apelacyjnego w Warszawie z 21 października 2011, sygn. VI ACa 420/2011; wyrok SN z 4 listopada 2011 r. (I CSK 46/11); postanowienie SN z 21 grudnia 2011, sygn. ICSK 310/11.

52. E. Łętowska, op. cit. Zachowują tu swoje znaczenie orzeczenia $S N$ wydane w poprzednim stanie prawnym (z 6 marca 1992 r., OSN 1992, poz. 90; z 19 maja 1992, OSN 1993, poz. 119; z 3 lipca 1991 r., OSN 1992, poz. 41).

53. R. Tolik, Czy w świetle art. 385(3) pkt 20 kodeksu cywilnego $w$ brzmieniu ustalonym przez ustawę z 2 marca 2000 r. (Dz. U. nr 22, poz. 271) zastrzeżenie zmiennej stopy oprocentowania kredytu jest niedozwolona klauzulq umownq?, „Prawo Bankowe” 2000, nr 7-8; E. Rutkowska, Niedozwolone ... 
Oprocentowanie i opłaty oraz zasady ich ustalania i zmian w bankowych wzorcach umów...

które uprawniają bank do podawania do wiadomości konsumentów treści wzorca kształtującego stosunek prawny zawarty na podstawie umowy w postaci wywieszania ich w oddziale banku oraz udostępniania ich konsumentowi tylko na jego życzenie, a także o te, które uprawniają bank do zmiany wzorca, nie przewidując jednocześnie możliwości odstapienia od umowy przez klienta (wypowiedzenia umowy). Zmiana wzorca umowy rachunku bankowego w zakresie stawek prowizji i opłat wymaga doręczenia posiadaczowi rachunku co najmniej zmienionych postanowień wzorca, z możliwością wypowiedzenia umowy przez konsumenta.

Dość liczne są wpisy dotyczące szeroko rozumianej odpłatności za usługi bankowe (opłat i prowizji stosowanych przez banki], w tym w związku z prowadzeniem rachunku bankowego, np. opłat pobieranych przez bank za wypłaty gotówkowe z konta osobistego w bankomatach należących do banku, pobieranych niezależnie od opłat za prowadzenie rachunku przez ten sam bank. Oprócz kwestii związanej z dopuszczalnością pobierania opłat i prowizji za prowadzenie rachunku bankowego, pojawiło się także bezpośrednio z tym związane i nie mniej istotne zagadnienie sposobu (trybu) dokonywania zmian tychże. 0 wszelkich zmianach taryfy w trakcie trwania umowy bank jest zobowiązany informować każdego klienta. Niedozwolone są także takie postanowienia, które uprawniają banki do podawania do wiadomości obowiązujących stawek prowizji i opłat przez wywieszenie w oddziałach taryfy opłat i prowizji oraz udostępnianie jej na życzenie posiadacza rachunku, informowania posiadacza rachunku o zmianach w cenniku usług za pomoca wywieszania taryfy opłat. Niedopuszczalne jest informowanie klienta o zmianach w taryfie w inny sposób niż doręczenie mu zmienionego wzorca i umożliwienie mu w ten sposób zapoznania się z jego treścią ${ }^{54}$. Tylko w drodze takiego postępowania można zagwarantować konsumentowi rzeczywistą ochronę przed jednostronnymi działaniami banku prowadzącymi do zmiany treści umowy.

Wśród klauzul abuzywnych znajdują się te dotyczące zastrzegania przez banki we wzorcach umownych żądania różnego typu opłat za czynności bankowe i ich obsługę, np. związane z prowadzeniem rachunku bankowego, mnożeniem tytułów do ich pobierania, a także kształtowaniem ich wysokości.

Przeprowadzona analiza postanowień wpisanych do rejestru klauzul niedozwolonych w zakresie usług bankowych, a w szczególności umów rachunku bankowego, pozwala na stwierdzenie, że banki najczęściej posługują się w swojej praktyce klauzulami nakładającymi na konsumenta obowiązki pieniężne nieadekwatne do świadczonej usługi (problem odpłatności za usługi bankowe).

Analiza dotychczas stwierdzonych przypadków niedozwolonych klauzul umownych, w szczególności w umowach rachunku bankowego, pozwoliła na stwierdzenie stosowania zapisów podobnych, lub wręcz tożsamych z nimi, w bankowych wzorcach umownych dotyczących prowadzenia IKE i IKZE objętych badaniem. W dalszej części szczegółowo omówione zostaną klauzule z dwóch obszarów: sposobu ustalania oprocentowania oraz opłat likwidacyjnych i innych.

\section{Sposób obliczania oprocentowania rachunków emerytalnych w kontekście klauzul abuzywnych}

Sposób obliczania stopy oprocentowania w wybranych umowach może budzić wątpliwości oszczędzających, zwłaszcza że niektóre wzorce umowne zawierają informacje nt. okoliczności zmiany

54. Wyrok SN z 17 lutego 2005 r., LexisNexis nr 374034, „Monitor Prawniczy” 2005, nr 6, s. 276. 
oprocentowania ale nie wskazują, w jaki sposób wyznaczone zostanie nowe oprocentowanie, tj. w którym kierunku i w jakim zakresie ulegnie ono zmianie po wystapieniu zmiany określonych wskaźników ${ }^{55}$. Jedynie w nielicznych wzorach umów oprocentowanie pozostaje w jasno określonej relacji do wysokości stóp procentowych na rynku międzybankowym (Tabela 3, poziom skomplikowania mechanizmu ekonomicznego określono wówczas jako 0) lub jasno określony jest zakres zmian wskaźnika bazowego, który uprawnia bank do zmiany oprocentowania. W większości umów rachunków bankowych oprocentowanie określane jest decyzją zarządu i choć musi pozostawać w związku ze zmieniającymi się wskaźnikami referencyjnymi, to często w umowach nie przedstawiono dokładnego sposobu jego wyznaczania. W niektórych z nich decyzja zarządu może pozostawać w dość „luźnej” relacji do zmian wskaźników referencyjnych, których zmiany moga być traktowane jako możliwość dokonania swobodnej zmiany oprocentowania, przy zachowaniu pewnych szerokich ram określonych w umowie (poziom skomplikowania mechanizmu ekonomicznego w poniższej tabeli określono wówczas na 3 lub 4). Rodzi to watpliwości o zgodność z prawem takich praktyk, zwłaszcza że w ciaggu pierwszych 12 miesięcy od zawarcia umowy oszczędzający jest związany opłatą likwidacyjną sięgającą nawet 100\% odsetek.

Tabela 3. Sposób ustalania oprocentowania rachunków oszczędnościowych oferowanych jako IKE / IKZE przez banki

\begin{tabular}{|l|l|l|c|}
\hline \multicolumn{1}{|c|}{$\begin{array}{c}\text { Nazwa } \\
\text { instytucji }\end{array}$} & \multicolumn{1}{|c|}{$\begin{array}{c}\text { Rodzaj stopy } \\
\text { procentowej }\end{array}$} & \multicolumn{1}{|c|}{$\begin{array}{c}\text { Czynniki oprocentowania } \\
\text { (czynniki bazowe/przesłanki zmiany) }\end{array}$} & $\begin{array}{c}\text { Skomplikowanie } \\
\text { mechanizmu } \\
\text { ustalania } \\
\text { oprocentowania }\end{array}$ \\
\hline $\begin{array}{l}\text { Bank BGŻ BNP } \\
\text { Paribas S.A. }\end{array}$ & $\begin{array}{l}\text { zmienna (WIBOR } \\
\text { 3M lub stopa } \\
\text { referencyjna NBP) }\end{array}$ & $\begin{array}{l}\text { WIBOR 3M (dla rachunków otwartych przed 2 stycznia } \\
\text { 2014) lub stopa referencyjna NBP (od 2 stycznia } \\
\text { 2014) }\end{array}$ & 0 \\
\hline $\begin{array}{l}\text { Bank } \\
\text { Millennium S.A. }\end{array}$ & $\begin{array}{l}\text { zmienna (decyzja } \\
\text { zarzadu) }\end{array}$ & $\begin{array}{l}\text { zmiany WIBOR, EURiBOR, WIBID o min. 0,001 p.p., } \\
\text { stopy rezerwy obowiazkowej od depozytów o min. } \\
\text { 0,001 p.p., którejkolwiek z podstawowych stóp NBP } \\
\text { o 0,001 p.p., jakiegokolwiek wskaźnika inflacji o min. } \\
\text { 0,001 p.p., zobowiązanie Banku do utworzenia } \\
\text { rezerw lub odpisów, zapłaty opłat i podatków } \\
\text { nieprzewidzianych w przepisach prawa w dacie } \\
\text { zawarcia umowy }\end{array}$ & 2 \\
\hline $\begin{array}{l}\text { Bank Polskiej } \\
\text { Spółdzielczości } \\
\text { S.A. }\end{array}$ & $\begin{array}{l}\text { zmienna (decyzja } \\
\text { zarządu) }\end{array}$ & zmiany stopy redyskonta weksli & 1 \\
\hline $\begin{array}{l}\text { Getin Noble } \\
\text { Bank S.A. }\end{array}$ & $\begin{array}{l}\text { zmienna (stopa } \\
\text { referencyjna NBP } \\
\text { lub WIBOR 3M] }\end{array}$ & $\begin{array}{l}\text { Stopa referencyjna NBP lub WIBOR 3M (dla rachunków } \\
\text { otwartych przed 2 stycznia 2014) }\end{array}$ & 0 \\
\hline
\end{tabular}

55. J. Rutecka-Góra i in., op. cit. 


\begin{tabular}{|c|c|c|c|}
\hline Idea Bank S.A. & $\begin{array}{l}2 \% \text { (pierwszy rok), } \\
\text { WIBOR 3M (kolejne } \\
\text { lata) }\end{array}$ & $\begin{array}{l}\text { Zmiany WIBOR3M, jeśli zmieni się o co najmniej 0,01 } \\
\text { p.p. (zmiana od 22. dnia miesiąca); zmiany WIBOR 3M, } \\
\text { 6M 1Y, stopy rezerw obowiązkowych od depozytów, } \\
\text { stóp podstawowych NBP - zmiana o min. 0,01 p.p., } \\
\text { inflacja roczna, półroczna, kwartalna - zmiana o min. } \\
\text { 0,2 p.p., zmiana oprocentowania trzech najlepszych } \\
\text { IKE (poza bankami spółdzielczymi) - do wysokości ich } \\
\text { średniego oprocentowania }\end{array}$ & 1 \\
\hline $\begin{array}{l}\text { ING Bank } \\
\text { Ślaski S.A. }\end{array}$ & $\begin{array}{l}\text { zmienna (decyzja } \\
\text { zarządu) }\end{array}$ & $\begin{array}{l}\text { W regulaminie IKE brak informacji, od czego zależy } \\
\text { stopa oprocentowania. W ogólnym regulaminie } \\
\text { wskazane jest, że zmiana może nastapić, gdy } \\
\text { zmienia się: stopa referencyjna NBP, WIBOR 1M, } \\
\text { wskaźnik inflacji GUS (miesięczny); korekta } \\
\text { oprocentowania w górę o nie mniej niż, 0,1 p.p. gdy } \\
\text { zmiana ref. o co najmniej 0,1 p.p., korekta w dół o max. } \\
\text { jednokrotność zmiany indeksu ref., gdy zmienia się } \\
\text { on o min. 0,1 p.p. (podwyższanie jednorazowe lub } \\
\text { stopniowe) }\end{array}$ & 4 \\
\hline $\begin{array}{l}\text { mBank S.A. } \\
\text { z oddziałem } \\
\text { zagranicznym }\end{array}$ & $\begin{array}{l}\text { zmienna (decyzja } \\
\text { zarządu) }\end{array}$ & $\begin{array}{l}\text { Gdy zmieniaja się: 1) stopy podstawowe NBP lub } \\
\text { stopa depozytów, 2) inflacja GUS roczna, kwartalna, } \\
\text { miesięczna o min. 0,3 p.p. 3) WIBOR, LIBOR, EURIBOR } \\
\text { 1M o min. 0,002 p.p. w stosunku do jakiegokolwiek } \\
\text { dnia z ostatnich } 6 \text { mies., 4) zmiany obowiazkowych } \\
\text { rezerw, oprocentowanie obligacji Skarbu Państwa (brak } \\
\text { wskazania, których i o ile), dodatkowe opłaty, podatki, } \\
\text { rezerwy itp. } \\
\text { Uwaga! w przyp. 1) możliwa zmiana oprocentowania } \\
\text { do 4-krotności zmiany bazowej, w pozostałych } \\
\text { przypadkach o max. } 1 \text { p.p. }\end{array}$ & 3 \\
\hline $\begin{array}{l}\text { Krakowski } \\
\text { Bank } \\
\text { Spółdzielczy }\end{array}$ & \begin{tabular}{|l} 
zmienna (decyzja \\
zarządu)
\end{tabular} & $\begin{array}{l}\text { Może ulec obniżeniu (tylko ten kierunek zmian } \\
\text { jest szczegółowo opisany) o wskaźnik obniżki: } \\
\text { stóp ustalanych przez RPP, indeksów inflacji GUS } \\
\text { (rocznych, kwartalnych, mies.), zmiany rentowności } \\
\text { rocznych bonów skarbowych, zmian w WIBOR i WIBID } \\
\text { (wszystkich), nowych rezerw, opłat podatków - } \\
\text { taka zmiana stanowi zmianę umowy. W przypadku } \\
\text { podwyżki (nie musi być uzasadniona) bank ma } \\
\text { jedynie obowiązek poinformowania o zmianie }\end{array}$ & 4 \\
\hline SGB BANK & $\begin{array}{l}\text { zmienna (zmiana } \\
\text { co } 6 \text { mies.) }\end{array}$ & $\begin{array}{l}\text { Oprocentowanie równe WIBID 6M - średnia } \\
\text { arytmetyczna z } 3 \text { miesięcy (III-V lub IX-XI) } \\
\text { przemnożona przez wskaźnik 0,835 ( } 1 \text { rok), 0,86 } \\
(2 \text { rok), 0,885 (3-5 rok), 0,91 (od } 6 \text { roku) }\end{array}$ & 2 \\
\hline
\end{tabular}

Uwagi: Poziom skomplikowania mechanizmu ekonomicznego: 0 - oprocentowanie pozostaje w ściśle określonej relacji do wysokości wskaźników referencyjnych i jego zmiana następuje automatycznie (nie ma także zróżnicowania sposobu obliczania oprocentowania w kolejnych latach], 1 - dokładnie określony jest zakres zmian wskaźnika bazowego, który uprawnia instytucję bankową do zmiany oprocentowania, zmiana następuje w drodze decyzji zarządu (lub automatycznie i jednocześnie występuje różny sposób obliczania oprocentowania dla kolejnych lat), 2 - oprocentowanie pozostaje w określonej relacji do wskaźników bazowych, jednak sposób jego obliczania jest skomplikowany, 3 - zmiana decyzją zarządu, gdy wystapi zmiana wskaźników referencyjnych, zakres ustalony dość luźno lub szeroko, jednak kierunek zmian zbieżny z kierunkiem zmian indeksów bazowych, 4 - zmiana decyzja zarządu, przy wystapieniu zmiany wskaźników bazowych, jednak brak pełnej informacji o kierunku i zakresie zmian, możliwy brak symetrii zmian oprocentowania.

Źródło: opracowanie własne. 
Wydaje się, że niejasny sposób ustalania oprocentowania rachunku emerytalnego może być sposobem na wprowadzanie ukrytych opłat w rachunkach, a odzwierciedleniem poziomu tych opłat (zakresu kosztów przenoszonych na klientów) może być zmniejszenie relacji oprocentowania rachunku do oprocentowania lokat na rynku międzybankowym. Bank może w ten sposób znacznie zmniejszyć atrakcyjność IKE / IKZE w stosunku do sytuacji pierwotnej, tj. gdy klient zawierał umowę. Takie zjawisko występować może także w sytuacji oferowania podwyższonego, promocyjnego oprocentowania przez stosunkowo krótki okres od zawarcia umowy, np. przez pierwsze 1-3 miesiące, a następnie wyznaczanie go w drodze decyzji zarządu banku. Możliwa utrata efektywności produktu na skutek relatywnego obniżenia oprocentowania środków jest kosztem dla klienta, a dla banku - korzyścią. Z punktu widzenia ekonomicznego skutek może być taki sam jak przy wprowadzeniu dodatkowej opłaty. Bank może w ten sposób przerzucać dużą część ryzyka swojej działalności na klienta, który nie jest zwykle profesjonalistą na rynku finansowym. Sprawa relacji oprocentowania IKE i IKZE oferowanych przez banki do wysokości stóp procentowych na rynku międzybankowym wymaga jednak głębszej i dalszej analizy ekonomicznej, wykraczającej poza cel i ramy niniejszego badania. Warto jednak wspomnieć, że od początku wprowadzenia IKE i IKZE obserwuje się spadek nominalnego i realnego oprocentowania kont emerytalnych ${ }^{56}$. W chwili obecnej wszystkie bankowe IKE i IKZE charakteryzują się ujemnym oprocentowaniem w ujęciu realnym i żaden z rachunków nie oferuje utrzymania realnej wartości zgromadzonych na nim środków.

Analiza wzorców umownych objętych badaniem pod kątem zamieszczania w nich niedozwolonych klauzul umownych dotyczących oprocentowania, z uwagi na ich podobieństwo lub wręcz tożsamość z tymi, które zostały już za takie uznane, pozwoliła stwierdzić, że takie postanowienia były w nich zamieszczone. W badanych bankowych wzorcach umownych (wzorach, umów, tabelach czy taryfach opłat i prowizji, regulaminach) dotyczących IKE i IKZE są postanowienia, które uprawniały do dokonywania dowolnych lub motywowanych niedostatecznie sprecyzowanymi i mało przejrzyście określonymi przesłankami zmian wysokości oprocentowania i tym samym - zmiany wzorców.

\section{Poziom opłat likwidacyjnych i innych opłat w bankowych produktach emerytalnych a niedozwolone klauzule umowne}

Kolejnym z kluczowych obszarów poddanych analizie był poziom opłat likwidacyjnych, tj. opłat pobieranych przez bank w sytuacji dokonania wypłaty, wypłaty transferowej bądź zwrotu w ciągu 12 miesięcy od zawarcia umowy. Warto zwrócić uwagę, że banki nie pobierają opłat za samo prowadzenie rachunków IKE i IKZE. Tabele opłat przewidują co prawda szereg usług, w przypadku których klient musi ponieść opłatę (np. dodatkowe zaświadczenia, wyciagi, informacje), jednak mają one raczej charakter dodatkowy, tzn. w sytuacji, gdy klientowi wystarcza standardowy (zwykle zdalny] dostęp do rachunku i gromadzi na nim środki przez co najmniej 12 miesięcy, z jego oszczędności emerytalnych nie zostanie pobrana żadna kwota, nawet jeśli po tym terminie przeniesie kapitał emerytalny do innej instytucji.

W razie jednak rozwiązania umowy przed upływem roku banki naliczają opłaty sięgające nawet $100 \%$ naliczonych odsetek (tabela 4.), co może rodzić pytanie o zasadność potrącanych kwot i ich relację do kosztów faktycznie ponoszonych przez instytucje finansowe z tytułu zerwania umowy.

56. Ibidem. 
Oprocentowanie i opłaty oraz zasady ich ustalania i zmian w bankowych wzorcach umów...

Spośród analizowanych ofert tylko Getin Noble Bank nie pobierał żadnej opłaty likwidacyjnej, natomiast pozostałe instytucje potrącały całość bądź połowę naliczonych odsetek lub stosowały opłaty kwotowe. Potrącanie całości lub nawet części odsetek bez jednoczesnego stosowania limitu kwotowego może doprowadzić do sytuacji, w której opłata likwidacyjna przewyższa kwotę wpłat na rachunek bankowy wniesionych w okresie funkcjonowania umowy. Sytuacja taka może wystapić, jeśli wcześniej dokonano wysokiej wypłaty transferowej, tj. przeniesiono do banku znaczne oszczędności emerytalne gromadzone wcześniej przez wiele lat w innej instytucji finansowej ${ }^{5 ?}$. Zupełnie niezrozumiałym jest również przypadek potrącania opłaty kwotowej, niezależnej od wartości zgromadzonych środków ani naliczonych odsetek (np. Bank BGŻ BNP Paribas, mBank, Krakowski Bank Spółdzielczy) - taka opłata może pochłoną́ nawet całość zgromadzonych środków w początkowym okresie oszczędzania. Autorkom nie wydaje się przy tym, aby miało to uzasadnienie w kosztach zawarcia umowy. Pomimo że ustawa o IKE i IKZE dopuszcza możliwość pobierania przez banki opłat likwidacyjnych, klauzule przewidujące potrącanie tak wysokich opłat moga zostać uznane za niedozwolone. Ich wysokość nie koresponduje bowiem z wysokościa ponoszonych przez banki kosztów. Znacznie niższe opłaty były już bowiem uznawane za klauzule niedozwolone.

Tabela 4. Opłaty likwidacyjne w IKE/IKZE oferowanych przez banki

\begin{tabular}{|c|c|c|}
\hline Nazwa banku & Wysokość opłaty & Uwagi \\
\hline $\begin{array}{l}\text { Bank BGŻ BNP } \\
\text { Paribas S.A. }\end{array}$ & $600 \mathrm{zł}$ & $\begin{array}{l}0 \text { zł w przypadku wypłaty transferowej } \\
\text { na rachunek w TFI BGŻ BPN Paribas S.A. }\end{array}$ \\
\hline $\begin{array}{l}\text { Bank Millennium } \\
\text { S.A. }\end{array}$ & $\begin{array}{l}\text { 100\% naliczonych odsetek (rozwiązanie } \\
\text { umowy przed upływem } 6 \text { mies.), } \\
50 \% \text { naliczonych odsetek } \\
\text { (po } 6 \text { mies.) }\end{array}$ & - \\
\hline $\begin{array}{l}\text { Bank Polskiej } \\
\text { Spółdzielczości S.A. }\end{array}$ & $\begin{array}{l}100 \% \text { odsetek naliczonych za pełne } \\
\text { miesiące oszczędzania }\end{array}$ & $\begin{array}{l}\text { Opłata nie wyższa niż odsetki za } 6 \\
\text { miesięcy naliczone według początkowego } \\
\text { oprocentowania }\end{array}$ \\
\hline $\begin{array}{l}\text { Getin Noble Bank } \\
\text { S.A. }\end{array}$ & $0 \mathrm{zł}$ & - \\
\hline Idea Bank S.A. & $\begin{array}{l}100 \% \text { naliczonych odsetek należnych } \\
\text { na dzień wypłaty }\end{array}$ & - \\
\hline ING Bank Śląski S.A. & 1\% środków, max. 300 zł & $\begin{array}{l}\text { przy zwrocie i wypłacie transferowej min } \\
100 \mathrm{zł}\end{array}$ \\
\hline mBank S.A. & $200 \mathrm{zł}$ & $\begin{array}{l}50 \text { zł w przypadku wypłaty transferowej } \\
\text { do instytucji, z którymi bank podpisał } \\
\text { umowę o współpracę (Generali Życie S.A. } \\
\text { i TFI Skarbiec S.A.) }\end{array}$ \\
\hline $\begin{array}{l}\text { Krakowski Bank } \\
\text { Spółdzielczy }\end{array}$ & $150 \mathrm{zł}$ & - \\
\hline SGB BANK & $5 \%$ środków & - \\
\hline
\end{tabular}

Źródło: opracowanie własne na podstawie regulaminów i tabeli opłat banków.

57. Chodzi np. o sytuację, w której oszczędzający przetransferował z innej instytucji finansowej na IKE w banku 150 tys. zł, następnie wpłacił tylko 500 zł, a opłata likwidacyjna pobrana za zerwanie umowy z bankiem po 5 miesiącach od jej zawarcia wyniosła 1000 zł (odsetki naliczone od całości zgromadzonych, w tym wcześniej przetransferowanych, środków]. 
Bazując na przeprowadzonej analizie treści wzorców umownych dotyczących umów o prowadzenie IKE i IKZE w bankach, poniżej zamieszczono wykaz klauzul dotyczących innych opłat, które moga zostać uznane za niedozwolone z uwagi na ich podobieństwo lub tożsamość do klauzul wpisanych do rejestru NKU oraz wskazanych w decyzjach Prezesa UOKiK (tabela 5.).

Tabela 5. Inne opłaty pobierane przy rachunkach IKE / IKZE oferowanych przez banki

\begin{tabular}{|c|c|c|}
\hline Nazwa banku & Tytuł pobrania i wysokość opłaty & Uwagi \\
\hline $\begin{array}{l}\text { Bank BGŻ BNP } \\
\text { Paribas S.A. }\end{array}$ & $\begin{array}{l}\text { Bardzo dużo tytułów do pobierania opłat za dodatkowe czynności } \\
\text { banku, m.in.: } \\
\text { - udzielenie, zmianę lub odwołanie pełnomocnictwa - } 20 \text { zł, } \\
\text { - sporządzenie zaświadczeń i wydanie opinii na wniosek klienta } \\
\text { - } 50 \text { zł, } \\
\text { - sporządzenie odpisów i kserokopii dokumentów - } 60 \text { zł, } \\
\text { - przyjęcie, odwołanie, zmiana dyspozycji wkładem na wypadek } \\
\text { - śmierci - } 20 \text { zł, }\end{array}$ & - \\
\hline $\begin{array}{l}\text { Bank } \\
\text { Millennium S.A. }\end{array}$ & $\begin{array}{l}\text { W Cenniku usług - stopy procentowe wskazano jedynie } \\
\text { wysokość opłaty manipulacyjnej za wypłatę środków przed } \\
\text { upływem } 12 \text { miesięcy od założenia konta. W OWU natomiast } \\
\text { zawarta jest jedynie informacja, że wysokość prowizji i opłat } \\
\text { za czynności związane z prowadzeniem rachunku określa Cennik } \\
\text { usług, który stanowi integralną część Umowy }\end{array}$ & $\begin{array}{l}\text { Bank zastrzega sobie } \\
\text { prawo do dokonywania } \\
\text { zmian Cennika usług } \\
\text { w zakresie zmiany } \\
\text { wysokości kosztów } \\
\text { operacji i usług } \\
\text { ponoszonych przez Bank } \\
\text { zwiazanych z obsługa } \\
\text { IKE i powiązanych z nim } \\
\text { usług, do których stosuja } \\
\text { się zapisy OWU }\end{array}$ \\
\hline $\begin{array}{l}\text { Bank Polskiej } \\
\text { Spółdzielczości } \\
\text { S.A. }\end{array}$ & $\begin{array}{l}\text { - } \text { duplikat wyciagu miesięcznego w placówce banku - } 5 \text { zł, } \\
\text { - wyciag dzienny / tygodniowy / dwutygodniowy wysłany } \\
\text { - } \text { spczta - } 5 \text { zł, } \\
\text { potwierdzenia realizacji przekazu za dokument - } 10 \text { zł, } \\
\text { - sporządzenie historii rachunku na wniosek Posiadacza: } \\
\text { za każdy miesiąc roku bieżącego za dokument - 3 zł, max. } \\
20 \text { zł za cały rok; za każdy miesiąc roku poprzedniego -5 zł, } \\
\text { max. } 30 \text { zł za cały rok, } \\
\text { - przyjęcie, zmiana lub odwołanie dyspozycji posiadacza } \\
\text { rachunku w sprawie przeznaczenia środków zgromadzonych } \\
\text { na rachunku na wypadek jego śmierci (za dokument ) - } 10 \text { zł }\end{array}$ & - \\
\hline $\begin{array}{l}\text { Getin Noble } \\
\text { Bank S.A. }\end{array}$ & $\begin{array}{l}\text { - sporzadzenie i wydanie opinii bankowej - } 20 \text { zł, } \\
\text { - wygenerowanie zbiorczej informacji o rachunku - } 20 \text { zł }\end{array}$ & - \\
\hline Idea Bank S.A. & $\begin{array}{l}\text { - } \text { sporządzenie i wysłanie wyciągu w formie papierowej } \\
\text { na podany przez posiadacza rachunku adres } \\
\text { do korespondencji po zakończeniu każdego miesiąca } \\
\text { kalendarzowego (opłata pobierana każdego miesiąca) - } 5 \text { zł, } \\
\text { - } \text { sporządzenie, na życzenie klienta, historii operacji w formie } \\
\text { papierowej - opłata za każdy miesiąc - } 5 \text { zł, } \\
\text { - wysłanie, na życzenie klienta, historii operacji w formie } \\
\text { papierowej - } 5 \text { zł, } \\
\text { - sporządzenie i wysłanie, na życzenie klienta, odpisu dokumentów } \\
\text { uznaniowych lub obciazżeniowych do rachunku - } 5 \text { zł, } \\
\text { - przygotowanie oraz wysłanie, na życzenie klienta, duplikatu } \\
\text { umowy lub umowy z aktualnymi danymi - } 5 \text { zł }\end{array}$ & $\begin{array}{l}\text { Wysokość tych opłat } \\
\text { jest najniższa wśród } \\
\text { badanych banków } \\
\text { i wydaje się najlepiej } \\
\text { odzwierciedlać } \\
\text { rzeczywisty koszt } \\
\text { ponoszony przez } \\
\text { bank za wykonanie } \\
\text { dodatkowych czynności, } \\
\text { za które jest pobierana }\end{array}$ \\
\hline
\end{tabular}


Oprocentowanie i opłaty oraz zasady ich ustalania i zmian w bankowych wzorcach umów...

\begin{tabular}{|c|c|c|}
\hline $\begin{array}{l}\text { ING Bank Ślaski } \\
\text { S.A. }\end{array}$ & $\begin{array}{l}\text { - wydanie w Oddziale Banku potwierdzenia (duplikatu) } \\
\text { wykonanej transakcji Klienta na rachunkach } \\
\text { oszczędnościowych (opłata za szt.) - } 5 \text { zł, } \\
\text { - sporządzenie na życzenie Klienta zaświadczenia / opinii } \\
\text { o rachunku oszczędnościowym / lokaty terminowej: za okres } \\
\text { ostatnich } 12 \text { miesięcy - } 20 \text { zł za } 1 \text { rachunek; za okres } \\
\text { wcześniejszy niż } 12 \text { miesięcy (za każdy rozpoczęty rok } \\
\text { kalendarzowy) - } 30 \text { zł za } 1 \text { rachunek, } \\
\text { - sporządzenie odpisu umów zawartych z Bankiem oraz innych } \\
\text { dokumentów - } 10 \text { zł za stronę A4, max. } 100 \text { zł }\end{array}$ & \multirow[t]{4}{*}{$\begin{array}{l}\text { Mnożenie tytułów } \\
\text { do pobierania opłat } \\
\text { i wysokości niezwiązane } \\
\text { z kosztami banku. } \\
\text { Zastrzeżenie uprawnienia } \\
\text { do zmiany tabeli opłat } \\
\text { i prowizji, które nie } \\
\text { stanowi zmiany umowy. }\end{array}$} \\
\hline mBank S.A. & $\begin{array}{l}\text { - sporządzenie i wysłanie cyklicznego wyciaggu miesięcznego } \\
\text { - } \text { p formie papierowej - } 5 \text { zł, } \\
\text { do rachue dyspozycji ustanowienia osoby/-ób uposażonej/-ych } \\
\text { - zmiana osoby/ób uposażonej/ych do rachunku IKE - } 15 \text { zł, } \\
\text { - odwołanie osoby/-ób uposażonej/-ych do rachunku IKE - } 15 \text { zł, } \\
\text { - opłata za wydanie zaświadczeń - } 40 \text { zł, } \\
\text { - opłata za duplikaty dokumentów - } 80 \text { zł, } \\
\text { - opłata za wydanie dokumentów niestandardowych - } 100 \text { zł }\end{array}$ & \\
\hline $\begin{array}{l}\text { Krakowski } \\
\text { Bank } \\
\text { Spółdzielczy }\end{array}$ & $\begin{array}{l}\text { - zaświadczenie o treści wnioskowanej przez klienta - } 15 \text { zł, } \\
\text { - opinia bankowa na wniosek klienta - } 20 \text { zł, } \\
\text { - odpis wyciagu z rachunku za bieżacy rok - } 5 \text { zł, } \\
\text { - odpis wyciagu z rachunku za każdy poprzednik rok - } 7,50 \text { zł, } \\
\text { stanowiącego podstawę księgowanania - } 3 \text { zł, } \\
\text { - opis jednego dowodu do wyciagu za każdy poprzedni rok } \\
\text { - } \text { ptanowiącego podstawę księgowania - } 5 \text { zł, } \\
\text { na rachunek znajdujący się w innym banku (dotyczy również } \\
\text { przelewu z tytułu realizacji przez Bank zajęcia wierzytelności } \\
\text { z rachunku bankowego) - przelew zewnętrzny - 2,30 zł; } \\
\text { przelew w systemie SORBNET2 na rachunek znajdujący się } \\
\text { w innym banku - przelew zewnętrzny - } 25 \text { zł } \\
\end{array}$ & \\
\hline SGB Bank SA & $\begin{array}{l}\text { - zmiana, odwołanie dyspozycji (oświadczenia) posiadacza } \\
\text { rachunku w sprawie przeznaczenia wkładu na wypadek } \\
\text { śmierci (za każde odwołanie albo zmianę) - 20,00 zł, } \\
\text { - realizacja dyspozycji spadkobierców od każdego spadkobiercy } \\
\text { - 15,00 zł }\end{array}$ & \\
\hline
\end{tabular}

Źródło: opracowanie własne na podstawie regulaminów oraz tabeli opłat i prowizji banków.

Analiza wzorców umownych objętych badaniem pod kątem zamieszczania w nich niedozwolonych klauzul umownych dotyczących pobieranych przez banki opłat, w tym opłat likwidacyjnych, z uwagi na ich podobieństwo lub wręcz tożsamość z tymi, które zostały już za takie uznane, pozwoliła stwierdzić, że takie postanowienia są także w nich zamieszczone.

W badanych bankowych wzorcach umownych (wzorach, umów, tabelach czy taryfach opłat i prowizji, regulaminach) dotyczących IKE i IKZE zidentyfikowano takie postanowienia, które uprawniały: do pobierania opłat likwidacyjnych i innych opłat związanych z prowadzeniem rachunków IKE i ich obsługa jako rachunków bankowych, mnożenia podstaw (tytułów) do ich pobierania, a także dowolnego kształtowania ich wysokości w oderwaniu od ponoszonych przez banki kosztów. Poza tym dotyczyły one źle skonstruowanej klauzuli modyfikacyjnej zapewniającej dokonywanie 
dowolnych lub motywowanych niedostatecznie określonymi przesłankami zmian treści tych wzorców [tabel opłat i prowizji] w odniesieniu do zmiany wysokości tychże opłat.

\section{Podsumowanie}

Banki, proponując konsumentom indywidualne produkty emerytalne (IKE i IKZE), wykorzystują także opracowywane przez siebie wzorce umów, co jest z jednej strony przejawem asymetrii kontraktowej, z drugiej zaś - informacyjnej. Generuje to potencjalną możliwość naruszenia interesów konsumentów w postaci stosowania w nich niedozwolonych klauzul umownych, w tym także w odniesieniu do odpłatności i sposobu jej określania oraz dokonywania zmian. Analiza stwierdzonych (wpisanych do prowadzonego przez Prezesa UOKIK rejestru NKU lub w dotychczas wydanych decyzjach Prezesa UOKIK) niedozwolonych klauzul umownych w bankowych wzorcach umownych (wzorach, umów, tabelach czy taryfach opłat i prowizji, regulaminach) pozwala na stwierdzenie, że podobne do nich lub wręcz tożsame można odnaleźć w badanych bankowych wzorcach umów o IKE i IKZE. Z pewnością wpływ na to miał fakt, że badane indywidualne produkty emerytalne oferowane przez banki miały formę oszczędnościowego rachunku bankowego - stąd też podobieństwo tychże. Niedozwolone klauzule w bankowych wzorcach umów o IKE i IKZE to w większości postanowienia uprawniające do dowolnego (lub motywowanego niedostatecznie sprecyzowanymi przesłankami) dokonania zmiany ich treści, w tym w szczególności w odniesieniu do zmiany wysokości oprocentowania czy opłat i prowizji, jak również do pobierania opłat i prowizji za różne czynności związane z prowadzeniem i obsługą tych rachunków, a także dowolnego kształtowania ich wysokości.

Te zakazane praktyki rynkowe stosowane przez banki w zakresie IKE i IKZE nie tylko prowadza do naruszenia interesów konsumentów poprzez pogorszenie ich sytuacji finansowej, ale także moga przyczyniać się do wypaczenia samej instytucji, której celem było zachęcenie do dodatkowego oszczędzania na przyszłą emeryturę.

Problem stosowania wzorców umownych w bankowym obrocie konsumenckich, także w zakresie indywidualnych produktów emerytalnych, winien być rozpatrywany z perspektywy granic swobody umów i ochrony słabszej strony umowy (konsumenta będącego posiadaczem takiego konta) i nadużywania jej przez stronę silniejszą (bank). Konieczne jest skuteczne eliminowanie niedozwolonych klauzul umownych i minimalizowanie zagrożeń związanych ze stosowaniem wzorców umownych przez profesjonalistów, także w obszarze IKE i IKZE.

Sporym problemem w wychwytywaniu nieuczciwych postanowień umownych stosowanych we wzorcach umownych jest kwestia obszerności tekstu oraz drobnego druku. Utrudnia to w znaczny sposób ich transparencję, stanowi przeszkodę w zrozumieniu treści postanowień umownych zawartych we wzorcach umownych przez tzw. zwykłych czytelników ${ }^{58}$. Utrudnia to możliwość znalezienia w tekście i uzmysłowienia sobie przez konsumenta tych newralgicznych postanowień, które w sposób najważniejszy kształtujajego prawa i obowiązki. Poza tym używanie w niektórych częściach wzorców umownych mniejszych liter wywołuje już dość powszechne stwierdzenie, że lekturę różnego rodzaju regulaminów i ogólnych warunków umów należy rozpoczą́ od tego, co zostało zapisane najmniejszymi literami, często także w zacieniowanych innym kolorem miej-

58. Szerzej o zrozumiałości i czytelności tych umów: J. Rutecka-Góra i in., op. cit., ale też E. Rutkowska-Tomaszewska, Ochrona... 
Oprocentowanie i opłaty oraz zasady ich ustalania i zmian w bankowych wzorcach umów...

scach. Zauważalne jest zamieszczanie ważnych postanowień, zawierających wyłączenia, wyjątki lub ograniczenia zasad głównych na końcu tekstu zasadniczego.

Efektywna ochrona konsumenta, jako „słabszej strony” w relacjach umownych z bankiem profesjonalnym przedsiębiorca - powinna prowadzić do rzeczywistego wyeliminowania z umów bankowych, w analizowanym przypadku z umów rachunku bankowego oferowanego jako IKE bądź IKZE, nieuczciwych klauzul. W szczególności dotyczy to tych, które odnoszą się do problemu szeroko rozumianej odpłatności za te usługi, sposobu ustalania ich wysokości oraz dopuszczalności ich ustalania w ogóle, a także różnego rodzaju tzw. klauzul modyfikacyjnych uprawniajacych do ich zmiany. Kwestia odpłatności za usługi finansowe, w tym także w odniesieniu do bankowych IKE i IKZE, jak się okazuje, jest takim obszarem, w którym szczególnie materializuje się zagrożenie stosowania klauzul abuzywnych. Sprawą niezwykle ważna jest eliminowanie tych klauzul z obrotu w ogóle, a więc zadbanie o to, by nie były one dalej stosowane przez banki we wzorcach umownych, a także o usuwanie skutków ich zastosowania w umowach już zawartych z konsumentami z wykorzystaniem wzorców dotyczących IKE i IKZE.

W ten sposób skutecznie chroni się konsumentów, którzy już zawarli takie umowy, a jednocześnie tych, którzy potencjalnie w przyszłości zawierając takie umowy, mogliby być narażeni na ich stosowanie. Chodzi o możliwość wszczęcia postępowania przez Prezesa UOKIK w ramach ochrony konsumentów podejmowanej przez tę instytucję winteresie publicznym. Niemniej niezwykle istotne jest rozbudzenie świadomości konsumentów, tj. posiadaczy kont emerytalnych, co do możliwości uruchomienia i zastosowania indywidualnej sankcji za stosowanie niedozwolonej klauzuli (ich bezskuteczności). Nade wszystko nieodzowne jest jej rzeczywiste zastosowanie w każdym przypadku stosowania klauzul abuzywnych przez bank, najlepiej w sposób bezsporny i dobrowolny, a jeśli nie będzie to możliwe - to w ramach alternatywnych metod rozstrzygania sporów, ostatecznie - procedury sądowej.

Wydaje się, że niezrozumiałe i rażąco naruszające interesy konsumentów klauzule umowne moga być jedną z barier upowszechnienia indywidualnych produktów emerytalnych ${ }^{59}$. Zwłaszcza, że brak generalnie regulacji porządkujących i limitujących wysokość opłat pobieranych przez różne instytucje finansowe prowadzące konta emerytalne (poza bankami produkty takie oferuja chociażby zakłady ubezpieczeń na życie, towarzystwa funduszy inwestycyjnych, powszechne towarzystwa emerytalne oraz domy maklerskie). Posiadacz konta IKE lub IKZE powinien być chroniony przed wprowadzaniem przez banki do wzorców umów różnych opłat dodatkowych bez swojej wiedzy, woli i świadomości. Różnice w wysokości opłat, jak również zmiany dokonywane jednostronne przez banki w tym obszarze, dyktowane konkurencją na rynku obniżaja zaufanie oszczędzających do instytucji prowadzących IKE i IKZE oraz zniechęcają do podejmowania trudnych decyzji dotyczących dodatkowego zabezpieczenia emerytalnego. Stosowanie w zakresie odpłatności za prowadzenie kont emerytalnych niedozwolonych klauzul umownych, nie tylko w bankowych wzorach umów o IKE i IKZE, może także poważnie wypaczać istotę tej szczególnej instytucji prawa emerytalnego i, w analizowanym przypadku, także prawa bankowego. Może to z kolei prowadzić do działań poważnie naruszających

59. Szerzej o barierach rozwoju dodatkowego zabezpieczenia emerytalnego w Polsce m.in.: J. Rutecka-Góra, Deficiencies in the supplementary pension market in Poland from the perspective of regulatory policy, „Acta Scientiarum Polonorum. Oeconomia" 2020, Vol. 19, No. 2, s. 51-59, doi:10.22630/ASPE.2020.19.2.17 oraz J. Rutecka-Góra, Inadequacies of regulations on supplementary pension plans in Central and Eastern European countries, “European Journal of Social Security" 2021, Vol. 23, Issue 3, s. 232-246, doi: 10.1177/13882627211038964. 
interesy ekonomiczne konsumenta oszczędzającego na emeryturę w długim okresie i powodować, że oferowane produkty będą dla niego nieodpowiednie i nieadekwatne do jego potrzeb, że nie będą spełniały celów i posiadać cech, które im przypisywano.

Skuteczne eliminowanie niedozwolonych klauzul umownych z umów konsumenckich jest problemem niezwykle istotnym - nie tylko w kontekście prawnym (rzeczywistego zastosowania przewidzianej za ich stosowanie sankcji], ale także społecznym i etycznym. Uwypukla on także kwestię bardziej ogólnej natury, jaka jest właściwe stosowanie przez wszystkich oraz skuteczne egzekwowanie prawa ochrony konsumenta w Polsce, w tym także polegające na przeciwdziałaniu i eliminowaniu skutków stosowania nieuczciwych, krzywdzących i wykorzystujących przewagę kontraktową profesjonalisty warunków umów, także w umowach o indywidualne konta emerytalne i indywidualne konta zabezpieczenia emerytalnego.

Powoduje to konieczność regularnego badania wzorców umów dotyczących indywidualnych produktów emerytalnych, nie tylko tych bankowych, także, jak się wydaje, przed ich wprowadzeniem na rynek ${ }^{60}$. Jest to uzasadnione tym, że stosowanie zachęt podatkowych w odniesieniu do produktów emerytalnych zawierających klauzule niedozwolone może powodować, zwłaszcza w przypadku niskiej świadomości prawnej i finansowej konsumentów, redystrybucję w kierunku instytucji finansowych oraz nieskuteczność dodatkowego zabezpieczenia emerytalnego. Poza tym stosowanie klauzul abuzywnych, zwłaszcza dotyczących opłatności za indywidualne produkty emerytalne, może oznaczać brak ich efektywności i niedostosowanie do potrzeb nabywających je konsumentów, a te szkodliwe praktyki rynkowe wymierzone są także w istotę tego produktu i sa przejawem missellingu.

\section{Wykaz źródeł}

Berthon J., Christoff L., Davydoff D., Fulea F., Gabaut L., Gunnarsdottir J., Houdmont A., Klages M., Kortesluoma N., Mujagić E., Prache G., Rossi M., Rutecka J., Šebo J., Silva F., Struwe K., Virdzek T., Viver J.M., Pension Savings. The Real Return. 2015 Edition, Better Finance, Brussels 2015. Dopierała Ł., Efficiency of Pension Products Offered by Life Insurance Companies: the Case of Individual Pension Accounts, „Finanse i Prawo Finansowe” 2017, nr 2 (14). doi: 10.18778/2391-6478.2.14.03. Dopierała Ł., Indywidualne konta emerytalne prowadzone przez zakłady ubezpieczeń. Efektywność inwestycyjna i zasady funkcjonowania, Wydawnictwo Uniwersytetu Gdańskiego, Gdańsk 2018. Kawulski A., Prawo bankowe. Komentarz, LexisNexis, Warszawa 2013.

KNF, Lista instytucji finansowych prowadzacych IKE według stanu na dzień 31 grudnia 2019 roku, Warszawa 2020, https://www.knf.gov.pl/knf/pl/komponenty/img/IKE_lista_podmioty_122019_69076.xls [dostęp: 23.12.2020].

KNF, Lista instytucji finansowych prowadzqcych IKZE według stanu na dzień 31 grudnia 2019 roku, Warszawa 2020, https://www.knf.gov.pl/knf/pl/komponenty/img/IKZE_lista_podmioty_122019_69080.xls [dostęp: 23.12.2020].

Kolek A., Sobolewski 0., OFE, PPK, IKE[+] - Zmiany w systemie emerytalnym 2019-2021. Analiza prawno-ekonomiczna, „Monitor Prawniczy. Dodatek” 2020, nr 8.

Łętowska E., Ustawa o ochronie niektórych praw konsumentów. Komentarz, CH Beck, Warszawa 2002.

60. Ibidem. 
Oprocentowanie i opłaty oraz zasady ich ustalania i zmian w bankowych wzorcach umów...

Mączyńska A., Šebo J., Voicu S.D., Carlucci E., Christoff L., Christensen L., Deinema M., Hagen J., Herce J. A., Houdmont A., Gabaut L., Popova Y., Grænge-Hansen L., Meštan M., Naacke G., Nacheva D., Nava C., Joab M., Prache G., Rutecka-Góra J., Url T., Long-Term and Pension Savings. The Real Return. 2020 Edition, Better Finance, Brussels 2020.

Marcinkiewicz E., Dobrowolne fundusze emerytalne w Polsce - analiza działalności i wyników inwestycyjnych, [w:] Współczesne problemy systemów emerytalnych. Wybrane zagadnienia, Chybalski F., Marcinkiewicz E. [red.], Wydawnictwo Politechniki Łódzkiej, Łódź 2015.

Maśniak D., Indywidualne konta zabezpieczenia emerytalnego jako sposób wzmacniania bezpieczeństwa socjalnego, „Gdańskie Studia Prawnicze” 2013, nr 2.

Niezbecka E., [w:] Umowa rachunku bankowego, w: Kodeksowe umowy handlowe, Kidyba A. [red.], LEX, Warszawa 2014.

Ofiarski Z., Prawo bankowe. Komentarz, Lex, Warszawa 2014.

Pieńkowska-Kamieniecka S., Rutecka-Góra J., Kowalczyk-Rólczyńska P., Hadryan M., Readability, efficiency and costliness of individual retirement products in Poland, "Equilibrium. Quarterly Journal of Economics and Economic Policy" 2021, Vol. 16, No. 1, doi: 10.24136/eq.2021.002.

Pyzioł W., Umowa rachunku bankowego, [w: ] System Prawa Prywatnego. Tom 8, Panowicz-Lipska J. [red.], CH Beck, Warszawa 2011.

Rutecka J., Bielawska K., Petru R., Pieńkowska-Kamieniecka S., Szczepański M., Żukowski M., Dodatkowy system emerytalny w Polsce - diagnoza i rekomendacje zmian, Towarzystwo Ekonomistów Polskich, Warszawa, grudzień 2014.

Rutecka-Góra J., Inadequacies of regulations on supplementary pension plans in Central and Eastern European countries, "European Journal of Social Security" 2021, Vol. 23, Issue 3, doi: $10.1177 / 13882627211038964$.

Rutecka-Góra J., Deficiencies in the supplementary pension market in Poland from the perspective of regulatory policy, "Acta Scientiarum Polonorum. Oeconomia" 2020, Vol. 19, No. 2, doi: 10.22630/ASPE.2020.19.2.17.

Rutecka-Góra J., Efekty zachęt podatkowych w dodatkowym systemie emerytalnym w Polsce, [w:] Ubezpieczenia. Wyzwania rynku, Kwiecień I., Kowalczyk-Rólczyńska P. [red.], Wydawnictwo CH Beck, Warszawa 2019, doi: 10.33119/978-83-8198-041-8 49-62.

Rutecka-Góra J., Efficiency of a supplementary old-age pension system - the case of Polish voluntary pension funds, "Financial Internet Quarterly e-Finanse" 2019, № 15 (3), doi: 10.2478/ fiqf-2019-0022.

Rutecka-Góra J., Bielawska K., Hadryan M., Kowalczyk-Rólczyńska P., Pieńkowska-Kamieniecka S., Zrozumiałość, przejrzystość i efektywność indywidualnych produktów emerytalnych w Polsce, Oficyna Wydawnicza SGH, Warszawa 2020, doi: 10.33119/978-83-8030-378-2.2020.202.

Rutkowska E., Niedozwolone klauzule umowne w bankowym obrocie konsumenckim, „Prawo Bankowe" 2002, $\mathrm{nr}$ ?/8.

Rutkowska-Tomaszewska E., Aktualne trendy i wyzwania w zakresie ochrony konsumenta na rynku finansowym: dokqd zmierza (powinna zmierzać) ochrona konsumenta?: kilka wybranych uwag, [w: Ekonomia jako dyscyplina naukowa i kierunek kształcenia: aktualne trendy i pożqdane zmiany, Rutkowska-Tomaszewska E., Kwaśnicki W. [red.], Difin, Warszawa 2020.

Rutkowska-Tomaszewska E., Current trends in consumer protection regulations in the financial services market in Poland, [w:] Consumer rights protection: threats and opportunities for 
enhancing consumer awareness, Smyczek S. [red.], Uniwersytet Ekonomiczny w Katowicach, Katowice 2020.

Rutkowska-Tomaszewska E., Idea ochrony konsumenta przez informację na rynku usług finansowych. Dokqd zmierza? (powinna zmierzać?), [w:] Informacja na rynku usług finansowych, Rutkowska-Tomaszewska E. [red.], Polskie Wydawnictwo Ekonomiczne, Warszawa 2019.

Rutkowska-Tomaszewska E., Manipulowanie informacja w zakresie odpłatności za usługi bankowe i prawne mechanizmy przeciwdziałania tym nadużyciom, [w:] Nowe koncepcje i regulacje nadzoru finansowego, Rogowski W. [red.], Oficyna Allerhanda, Kraków-Warszawa 2014.

Rutkowska-Tomaszewska E., Misselling i inne nadużycia wobec konsumentów na rynku usług finansowych, [w:] Nadużycia wobec konsumentów na rynku finansowym: wykrywanie, przeciwdziałanie, zapobieganie, Jurkowska-Zeidler A., Rutkowska-Tomaszewska E., Wiktorow A., Monkiewicz J. [red.], PWN, Warszawa 2020.

Rutkowska-Tomaszewska E., Ochrona prawna klienta na rynku usług bankowych, Wolters Kluwer, Warszawa 2013.

Rutkowska-Tomaszewska E., Prawo ochrony konsumenta usług finansowych w świetle założenia racjonalnego ustawodawcy: kilka wybranych uwag, „Acta Universitatis Wratislaviensis. Przegląd Prawa i Administracji" 2020, nr 120, cz. 2, doi: 10.19195/0137-1134.120.85.

Rutkowska-Tomaszewska E., Usługi finansowe - dobrodziejstwo i (czy) zagrożenie dla konsumentów? Czy ochrona konsumenta usług finansowych jest obecnie efektywna i wystarczajaca?, [w:] Ochrona konsumenta na rynku usług, Jagielska M., Sługocka-Krupa E., Podgórski K. [red.], CH Beck, Warszawa 2016.

Sieradzka M., Naruszenie obowiqzku informacyjnego we wzorcu umowy o prowadzenie indywidualnego konta emerytalnego (IKE) przez bank. Glosa do wyroku s. okręg. z dnia 3 grudnia 2013 r., XVII AmA 89/13, LEX/el. 2015.

Skubisz-Kępka K., [w:] Kodeks cywilny. Komentarz. Tom III. Zobowiqzania. Część ogólna (art. 353534], Fras M., Habdas M. [red.], Wolters Kluwer, Warszawa 2018.

Sowiński T., Finanse ubezpieczeń emerytalnych, Wolters Kluwer, Warszawa 2009.

Sychowicz M., Komentarz do art. 725, [w:] Komentarz do Kodeksu cywilnego. Księga trzecia. Zobowiqzania. Tom II, Bieniek G. [red.], LexisNexis, Warszawa 2011.

Szuszkiewicz J., Naruszenie bankowej umowy o prowadzenie rachunku IKE, „Monitor Prawa Bankowego" 2018, nr 3.

Tolik R., Czy w świetle art. 385(3) pkt 20 kodeksu cywilnego w brzmieniu ustalonym przez ustawę z 2 marca 2000 r. (Dz. U. nr 22, poz. 271) zastrzeżenie zmiennej stopy oprocentowania kredytu jest niedozwolona klauzulq umownq?, „Prawo Bankowe” 2000, nr 7-8.

Wesołowska I., Niedozwolone postanowienia umowne, [w:] Standardy wspólnotowe w polskim prawie ochrony konsumenta, Banasiński C. [red.], Warszawa 2004.

\section{Abusive clauses concerning interest rate changes and fees in individual retirement products offered by banks in Poland}

In the process of concluding contracts for individual retirement accounts and individual retirement security accounts, model contracts are used which may contain abusive clauses. The article presents the results of empirical research covering the majority of model forms of individual pension products 
Oprocentowanie i opłaty oraz zasady ich ustalania i zmian w bankowych wzorcach umów...

offered by banks in Poland, which confirm the occurrence of abusive clauses in these models that infringe consumer interests. They concern in particular changes in interest rates, as well as the basis for charging, determining the amount of and making changes in the fees charged by banks. The subject of the study covered both the construction of the analysed IKE and IKZE offered by selected banks, as well as their model contracts. The aim was to examine the content of bank model contracts relating to these pension products for the application of prohibited clauses relating to fees for these pension products, in particular as regards the method of determining the interest rate, as well as the amount of fees charged, including liquidation fees. The following research methods were used: a critical analysis of the literature, case law of the SACC and entries in the register of NKU kept by the President of the OCCP, and decisions of the President of the OCCP, as well as an economic and legal analysis of IKE and IKZE as bank products.

Keywords: individual retirement accounts, individual retirement security accounts, abusive clauses, model contracts, interest rates, cancellation fees.

DR HAB. JOANNA RUTECKA-GÓRA - profesor Szkoły Głównej Handlowej w Warszawie, Zakład Demografii Instytutu Statystyki i Demografii w Kolegium Analiz Ekonomicznych SGH w Warszawie. Zajmuje się ubezpieczeniami, zarówno społecznymi, jak i gospodarczymi, zagadnieniami oszczędzania i edukacją finansową. Autorka i współautorka publikacji, które wyróżnia konsumenckie spojrzenie na funkcjonowanie systemów emerytalnych, rynków ubezpieczeniowych i finansowych.

e-mail:jrutec@sgh.waw.pl

ORCID: 0000-0002-2509-8599

DR HAB. EDYTA RUTKOWSKA-TOMASZEWSKA - profesor Uniwersytetu Wrocławskiego, pracownik naukowo-dydaktyczny Wydziału Prawa, Administracji i Ekonomii. Specjalizuje się w problematyce funkcjonowania rynku finansowego i jego regulacji, ze szczególnym uwzględnieniem usług finansowych, a zwłaszcza ochrony klienta (konsumenta) na tym rynku. Autorka licznych publikacji oraz organizatorka konferencji z zakresu wskazanej problematyki badawczej.

e-mail: edyta.rutkowska-tomaszewska@uwr.edu.pl

ORCID: 0000-0001-9359-7034 
